\title{
المعارف العامة
}

يتناول أطر الفضاء الإلكتروني والحرب

الإلكترونية و البرامج الخبيثة و الفيروسات،

مع التحديات الدولية المعاصرة للهجمات

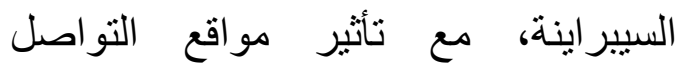

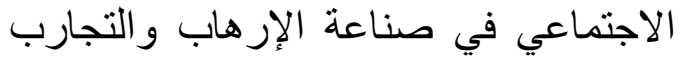

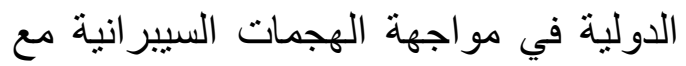

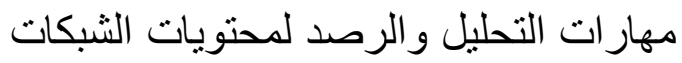
الاجتماعية عبر الفضاء السيبراني.

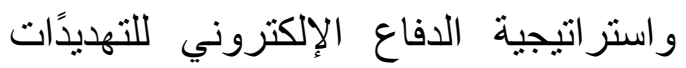
السيير انية.
الإنترنت

1

الفضاء الإلكتروني... التحديات الأمنية المعاصرة ، إعداد: عمار ياسر البابلي،

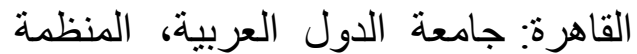
العربية للتربية والثقافة و العلوم، معهد

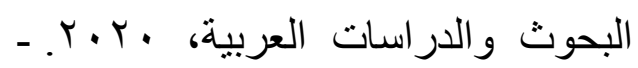
171 ص ؛ ؟ ז سم . - (دراسات

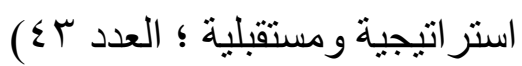

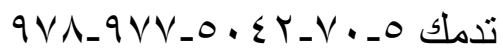

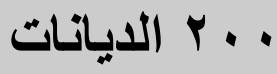

أن الصدق درة ثمينة في تاج الأخلاق فقد

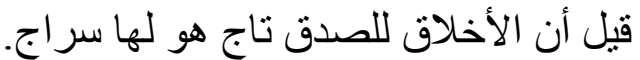

\section{الثقافة الإسلامية}

r

ـ تعليم المتعلم طرق التعلم، تأليف: برهان الإسلام الزرنوجى ـ ـ طا ـ ـ الثرقية:

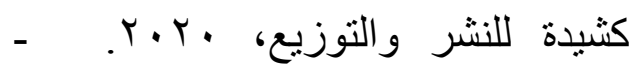

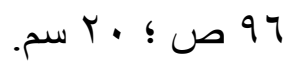

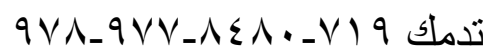

الحقيقة ان عناية الأمة الإسلامية بالتعلم والتعليم برزت ملامحها منذ أول نزول للوحى على خاتم الأنبياء، وقد بذل الصحابة
الآداب والأخلاق الإسلامية r الصدق مأثرة وأثره في حياة المسلمين، تأليف: عماد محمد على عيسى .- طا ا. --

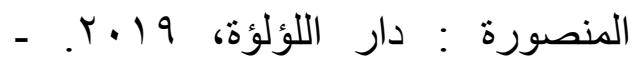

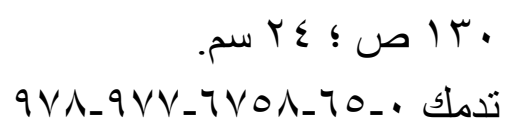
يبين كيف تغيرت الأخلاق وتبدلت وكسدت سوقها، وبارت بضائع أهلها فبعد أن كان الرجل يزكى يحسن الخلق ويمدح بعفة

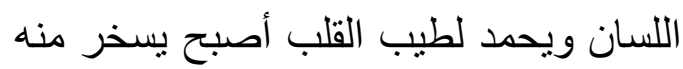
ويقال عنه أنه ضعيف على عكس سليط اللسان وخبيث النفس أصبح يمدح. والحقيقة 
إن قصه ميلاد سيدنا موسى تحظى وتنال شرف الذكر في القرآن الكريم؛ لما تحمله من

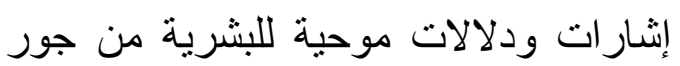

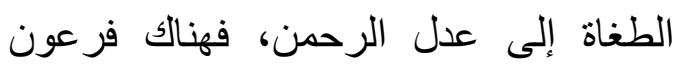
و هامان وجنودهما، و هناك من يقسم الثنعب الثب أو الثعوب إلى شيع وطوائف وطبقات،

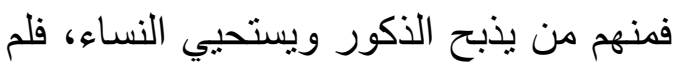
يحقق الذل و الاستعباد، بل تعثرت الأدور وبنات الناه

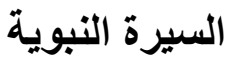

7

سنة الله في جهاد سيدنا رسول الله صلى الله عليه وسلم، تأليف: رشيد كهوس. - سلان طا. - المنصورة: دار الكلمة للنشر

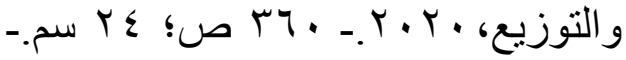
(نحو قر اءة جديدة للسيرة النبوية)

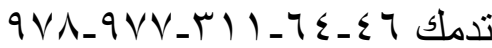
يهذف إلى ترسيخ الو عي السني في العقل المسلم، من خلال دراسة الجهاد النبوي في الني العهدين المكي و المدني من المنظور السني القرآني الجامع والمقصود بالجهاد في هذا الكتاب هو بذل الجهد لتحقيق مقاصد الإسلام

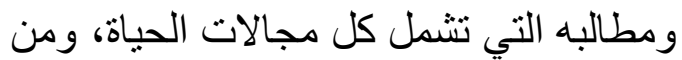
ثم فإن تتبع تللك السنن الإلهية الكلية في المفهوم الكلي للجهاد النبوي والوعي بلإن بها، و العمل بمقتضياتها يشكل سبيل الخروج من الفي لئهي وحدة التخلف، واسترداد الفاعلية، و إحياء الأمة، و استشر اف المستقبل.
و التابعون وسائر العلماء في ترسيخ العملية التعليمية في الثقافة الإسلامية، وحرص الترسيخ التعلية علماء المسلمين على تعزيز هذه العملية من خلال مؤلفات تربوية وبيان الصورة المثالية

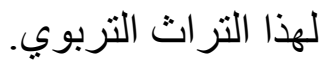

\section{الادفاع عن الإسلام}

$\varepsilon$

هصل الدين عن الدولة تاريخيًا وفكريًا، وموقف الدعوة الإسلامية منه، تأليف: مجدي عبدالهادي، ومحمد أبو المكارم

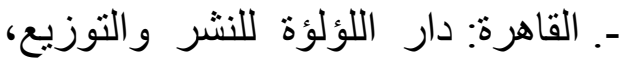

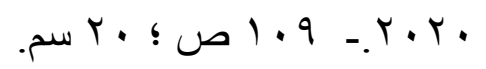

مع المطالبة الجماهيرية المسلمة بتطبيق الثريعة الإسلامية يقوم العلمانيون بالهجوم على الثريعة الإسلامية، واتهامها بأنها غير الإندام صالحه في العصر الحاضر؛ لأن في نظر هم الإنها

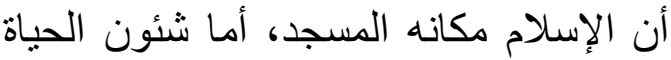
فلا شأن لله بها، فقد وقف العلمانيون صفا لإنا

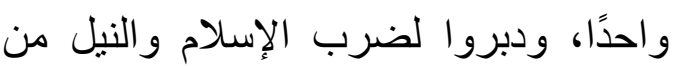

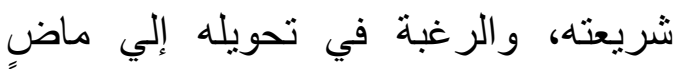
وذكريات من التاريخ.

\section{قصص الأنبياء}

0

الإعجاز النفسي في قصص الأنبياء موسى عليه السلام، تأليف: عبد الرحمن الاعن الألياء عسل.- القاهرة: النخبة للطباعة و والنشر

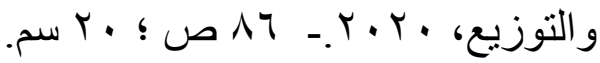

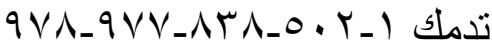


للناس أحكام الثريعة الإسلامية في تجهز البنت من مير اثها أو شر اء نصيب البنت بأقل من ثمنه، وحكم تفضيل بعض الأبناء في الهبة. 9

مقومات الدولة المدنية، تأليف: حاتم

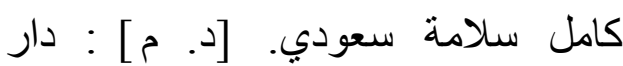

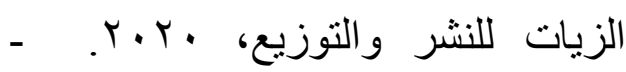

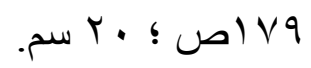

إن إقامة حكم رشيد في دولة إسلامية قد

يكون صعب؛ لاستحالة إقامة دولة إسلامية

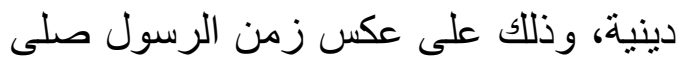
الله عليه وسلم، ومن بعده الخلفاء الر اثندين،

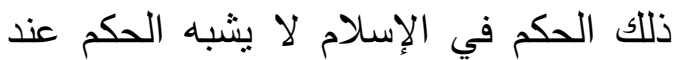

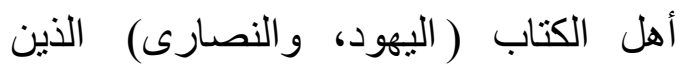
يستمدون أحكامهم من آباء المعابد و الكنائس؛ ولذلك كان حكم الدولة الإسلامية حكمًا مدنيًا. 1.

\section{الهدًاية والإعلام بما يترتب على قبح} القول من الأحكام، تأليف: برهان الدين

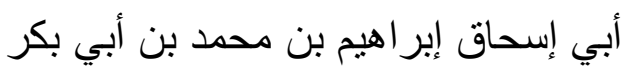

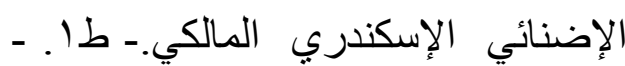

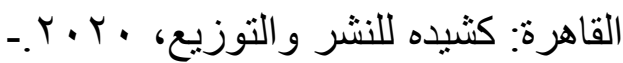

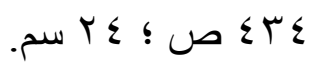
حذر الثرع الحنيف من قبح القول

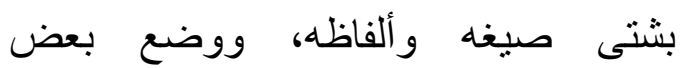
العقوبات زجرًا لمن يتلفظ به؛ حتى تستقيم

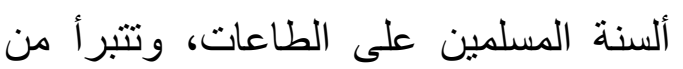

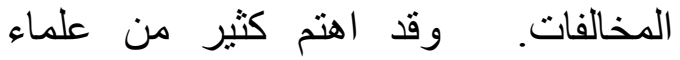
المسلمين بييان ما بترتب على الكلمة الخبيثة
V

مناهج الكرام من كلام خير الأنام عليه

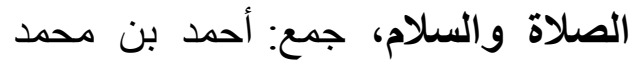
أبو العينين؛ تحقيق: محمد ناصر الدين الألباني. طا. القاهرة: دار اللؤلؤة للنشر

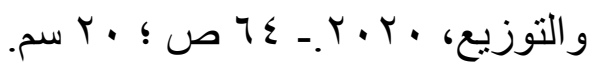
إن السنة وحي من الله أجر اها على لسان مصطفاه عز وجل، ويتضح ذللك في قراءة السنن الأربعة؛ لما فيهم من قواعد نافئحة وإحياء لكلام الرسول، فنجد أن أبا داوود فئد برع في جمع أبواب كتاب الأدب، وتميز

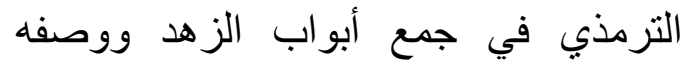
القيامة، وكذلك برع النسائي في كتاب الزينة وتفرد بكتاب الاستعاذة، وابن ماجه تفرد

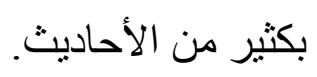

\section{الفقه الإسلامي}

$\wedge$

مسائل معاصرة في الميراث والوصية

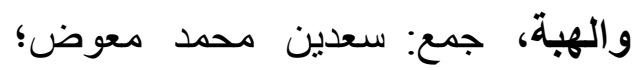
تقديم: وحيد بن عبد السلام بالي، وأبو

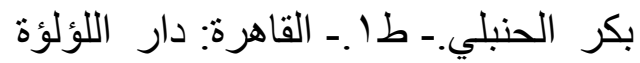

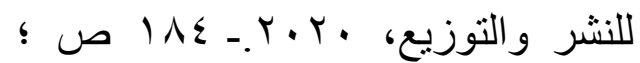
لقد أنزل الله شرعه لينظم بناء جميع أمور حياتتا، فعلى كل مسلم أن لا يقدم على لئل أمر حتى يسأل أهل العلم ما ينبغي أن يفعل حتى يعدل حياته وفق شرع اله تبارك

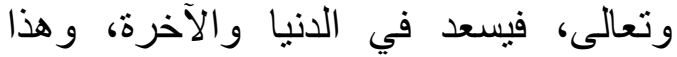
واجب على العلماء وطلبة العلم أن يبينوا 
ir

كثف البصيرة عن حقيقة التوسل والوسيلة، تأليف: رجب عبدة عند السميع

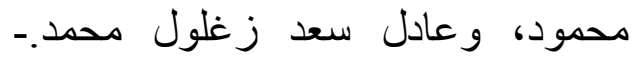

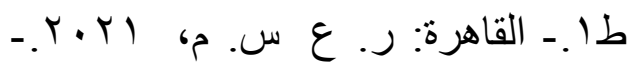

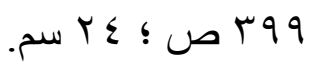

شرح بعض من المفاهيم، وتأصيل

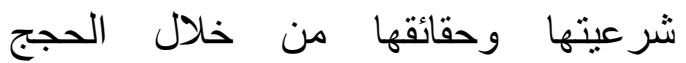
و البر اهين القاطعة نقلًا و عقلًا، وسير أغوار كل مفهوم على حدة في إطار إسلامي صحيح. نجد التباس بعض المفاهيم على هلى

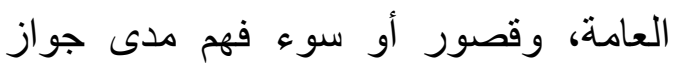
نسبة أو إضافة التأثنر إلى الأسباب أو أو أونى

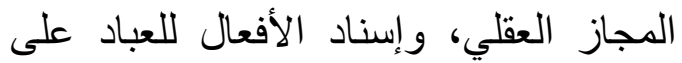

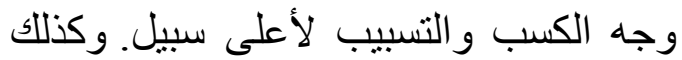
الاشتر اك اللفظي لبعض الألفاظ بين الخالق ولق ولى و المخلوق، و الخلط في الفهم والاستدلال بين

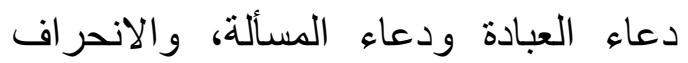
و الخلل عند البعض في فهم آيات التوحيد في ولي ولهاء

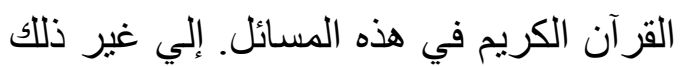
من القضايا العديدة التي تكثف فن عنها في سبيل تصحيح طريق التصوف السني السليم لخطاب ديني جديد.
القبيحة من أحكام شرعية، وكان من بين

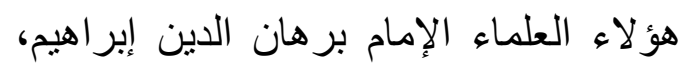

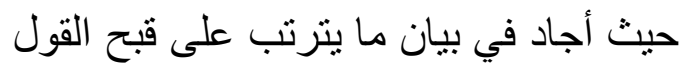

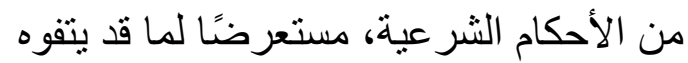

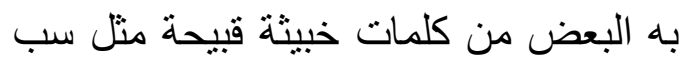
الله تعالى، أو سب نبيه، أو سبب الأنبياء عليهم الصلاة والسلام، أو سب الب الملائكة

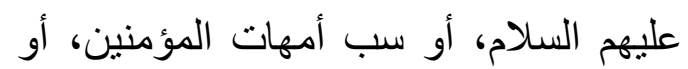

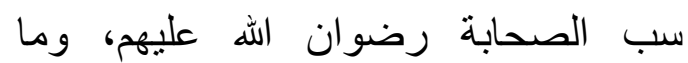
يترتب على قائل ذلك من أحكام.

\section{التصوف}

11

التعرف لمذهب أهل التصوف، تأليف: أبو بكر محمد بن إسحاق الكالاباذي؛ ضبط وتعليق: أحمد شمس الدين. القاهرة:

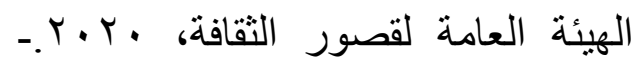

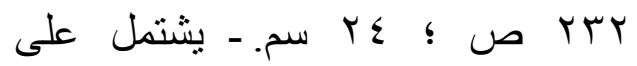
إرجاعات ببليو جر افية. يعتبر من أقدم وأدق كتب التي تناولت هذا العلم بمصطلحاته ورجاله، وفقد وضعنه

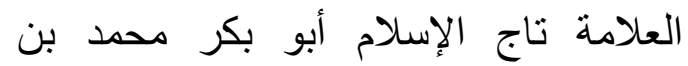
اسحاق البخاري الكلاباذي، فجاء هذا الكتاب الإناج

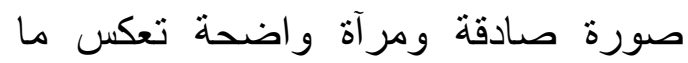
وصل إليه القدم من مواجيدهم ومجاهدًاتهم وهذا المصنف لم يكتف بذكر الأسماء وسرد الأقو ال وحكايات الأحوال، بل اتبع في كتابه

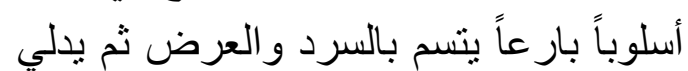

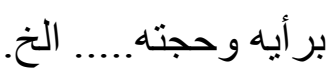




\section{ب. . ب العلوم الاجتماعية}

وعلم النفس، إلا أنه يركز على دراسة الإنسان ونظمه الاجتماعية في حالته البدائية الفطرية، وذللك مقابل دراساته في حالته المتطورة المتحضرة التي تقع في اختصاص ودل علم الاجتماع. والأنثروبولوجيا علم الانسان،

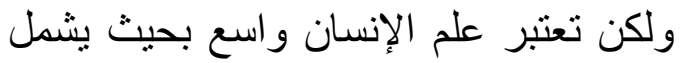

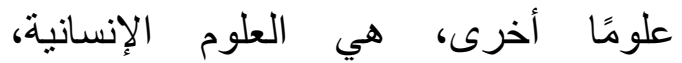

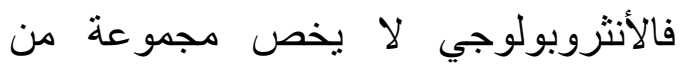
الناس بدراسته، أو حقبًا تاريخية معينة ينصب عليها اهتمامه، بل يهتم بالأثكال الأولية للإنسان.

10

أوروبا: التطرف العنيف وسبل المعالجة، حابة

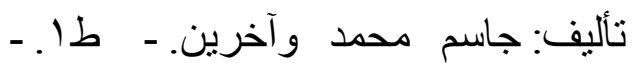

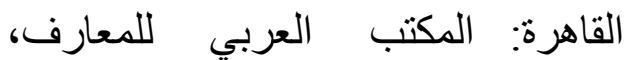
•

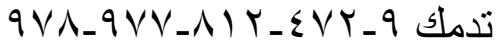

يتناول الجماعات المتطرفة في أوروبا بكل أنواعها ودرجاتها، أبرزها تنظيم

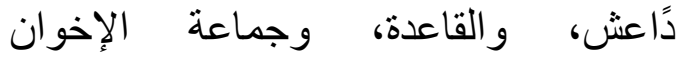
المسلمون، إلى جانب التنظيمات المحلية دًاخل أوروبا، وتهديدات الجماعات المتطرفة إقليميًا ودوليًا، أبرزها، ونا، سوريا، و العراق، وليبيا، و إفريقيا، وجنوب شرد آيا،

\section{علم الاجتمـاع}

ir

أبناء بلا مشاكل!!!: كورس مكثف لعلاج

المشكلات المعاصرة للأبناء، إعداد:

مصطفى النجار. - طا ــ القاهرة: مكتبة

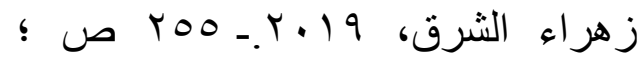

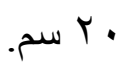

يُحيط بكثير من المشاكل المعاصرة التي

تواجه الأمهات والآباء في كل يون يوم وكل لحظة في تربية أبنائهم. وذللك من خلاءل خبرة طويلة في مجال التربية، ومن خلال

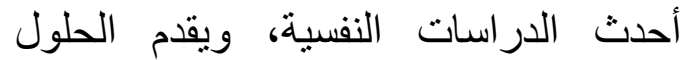
العملية الواجب اتباعها في تنشئة أبناء أسوياء ومتميزين في شتى مجالات الحياة، ويوضح معالم الطريق النفسي للتربية الصحيحة، مما يؤثر علينا و على أبنائنا الكثير من الجهد و الكثير من المتاعب.

$1 \leq$

الأنثروبولوجيا وقضايا الإنسان والمجتمع، إعداد: إيهاب عيسى، وطارق

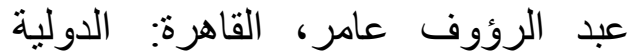

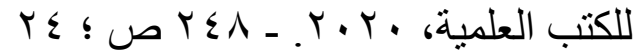

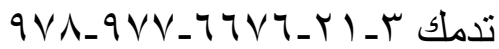
تعتبر الأنثروبولوجيا أحد العلوم الإنسانية، وهي العلوم التي تدرس الإنسان

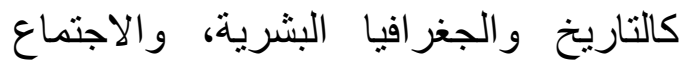


العلمي و الموضوعي من الإشكالية بعيدًا عن

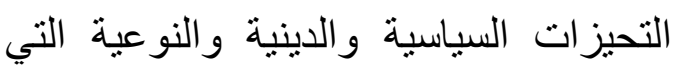
كثيرًا ما تشوش على المعالجات العلمية

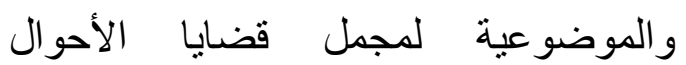
الثخصية. ويلقي نظرة سريعة على أبعاد

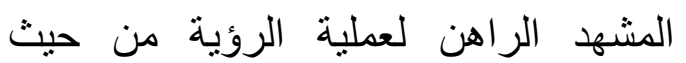

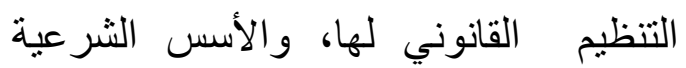
لحقوق الرؤية و الحضانة. 11

عالم في العراء الإعلام الجديد والثقافة

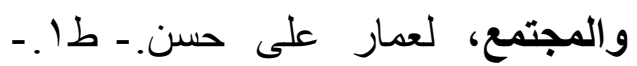

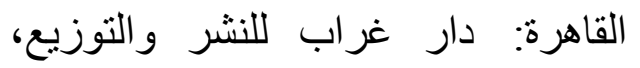
. . . . . .

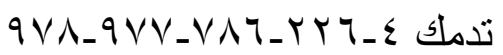

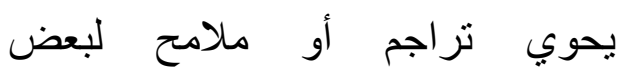
الشخصيات الأدبية، ومقاربات نقدية حول

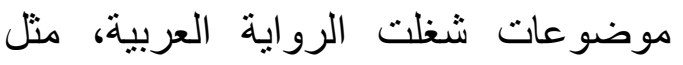
التصوف، و الريف، وحال الأقليات الدينية. كما بطرح روئ نظرية حول أثنكال الكتابة

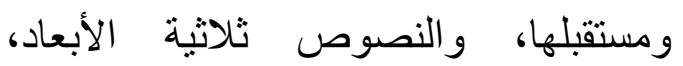

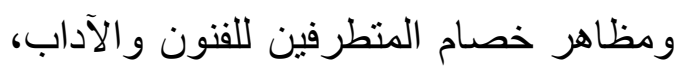
و الفروق الجوهرية بين ثقافة السترة وثثافة الندرة، وهذه الموضو عات في مجملها تدور

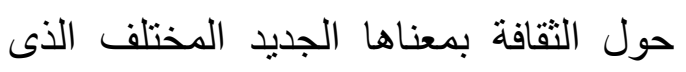
يتعدى قضايا الفنون والآداب إلى ما يقع في الجي قلب القضايا الإعلامية و الظواهر الإن الاجتماعية و السياسية من معارف وقيم ومثل.
17

التربية البيئية والتتمية المستدامة: بين السياسات الاقتصادية للاول والتحليل التقني للآثار الصحية، تأليف: علي سعد الأول ولهادية

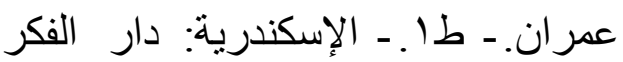

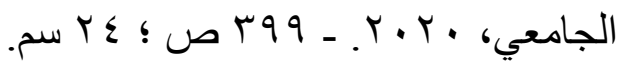

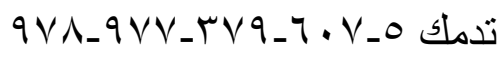
تعتبر التتمية المستدامة هدفًا من أهداف السياسات الاقتصادية في كل دول العالم،

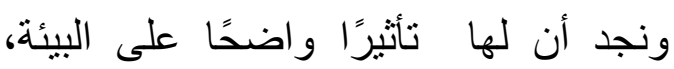
و على الموارد الطبيعة، و وعلى مستقبل

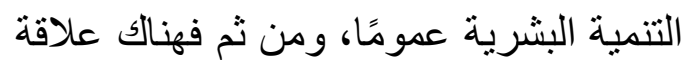
متبادَلَة بين التنمية المستدًامة وبين البئة البئة. ويتطلب ذللك تنمية الوعي البيئي، و غرس لئس شعور بالمسئولية تجاه البيئة.

IV

حقوق الروئية والاستضافة كآليات الحماية القانونية والاجتماعية للأسرة المصرية، لأحمد حسين حسن. القاهرة:

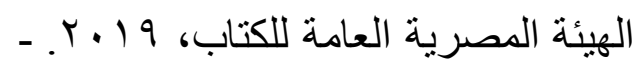
تو 9 ص ص 19 ت تدمك يطرح قضية الرؤية بأبعادها وتشابكاتها،

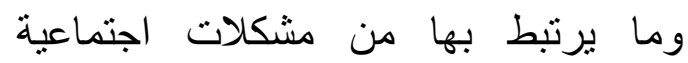
ونفسية، وذللك بالاستناد إلى معطيات ميدانية

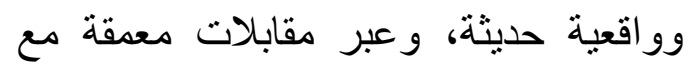

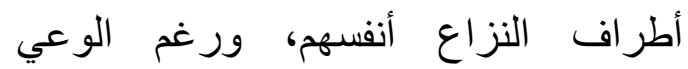
و التسليم بصعوبة التعميم من نتائج الدراسة الراهنة في ضوء عدة اعتبارات منهجية مشار إليها في موضعها، فقد حاول الاقتر اب أبها 
وزوجة الابن، وكيفية تحقيق السعادة لكل الاسرة، و إسعادها هي الأخرى؛ لأن كل هذا يساهم في تكوين شخصيتها، ونظرتها إلى والى لإن هي نفسها.

r)

المعتقدات والأخطاء الثائعة في تربية الأطفال، تأليف: فرج عبده بيصار. طا ــ القاهرة: الهيئة المصرية العالية العامة

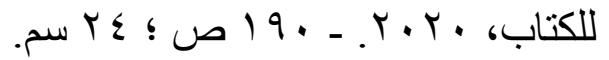
يشتمل على إرجاعات ببليو جر افية.

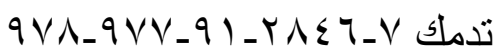

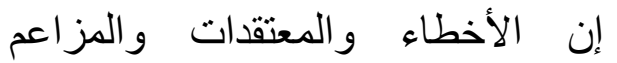

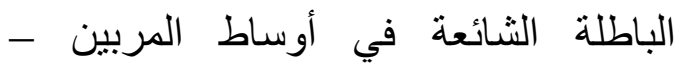

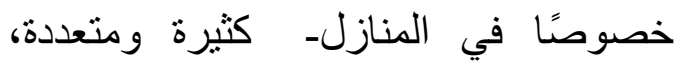
وتأتى كثرتها وتتعدادها بتعدد التقافات و اختلافها، وأيضًا بتعدد الطبقات الاجتماعية و العلمية، فكل مجتمع قد يختلف عن غيره في مثل هذه الأخطاء و المعتقدات، وقد يكون الاختلاف في المجتمع الو احد كبيرًا، ومعظم هذه الأخطاء والمعتقدات قد يكون أحد أسبابها متوارثًا ومتناقلًا من جيل إلى جيلى جيل، ولا يفكر أحد من هذه الأجيال في البحث و التمحيص ور اء تللك الأخطاء و المعتقدات. r

نساء الطبقة الوسطى في مصر خلال

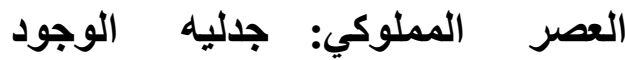
والإنكار، تأليف: إيمان صلاح عطاطاة.-

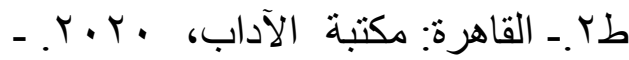
تومك 97 تدمك
19

علم النفس الاجتماعى، إعداد: إيهاب عيسى، وطارق عبد الرؤوف عامر.طا. - القاهرة: الدولية للكتب العلمية،

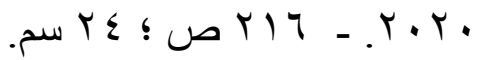
يثتمل على إرجاعات بيليوجر افية.

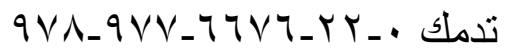
يدور موضوع على النفس الاجتماعي بصفة عامة حول دراسة الظواهر النفسية، كما تتمثل في السلوك الاجتماعي المتعدد

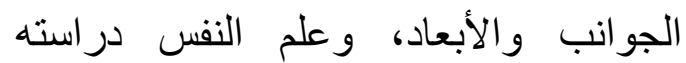
للإنسان يأخذ في اعتباره أن الإنسان كائن اجتماعي محكوم في تشكيله وتكوينه في الجني نموه بالوسط الذى يعيش فيه، وإن علم النفس لهن الاجتماعي هو عبارة عن محاولات علمية منظمة لدر اسة سلوك الفرد مؤثرًا أو متأثرًا بسلوك الآخرين.

$r$.

كيف تصبحين امراه جذابة، تأليف:

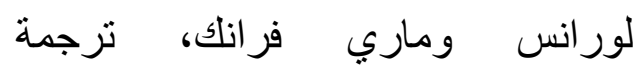

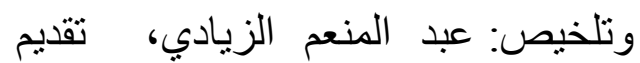
و ور اجعة: حازم عوضين. الجيزة: وكالة

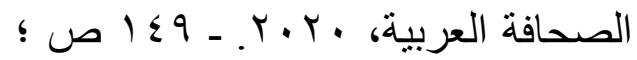
( ) يعتبر من أهم الكتب في مجاله، ولم يفقد

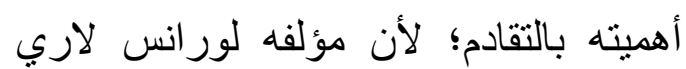
كيلو فر انك كان من كبار المهتمين بالأسرة و الطفولة، وشاركته زوجته في هذا المجال، وتتاول الكتاب علاقة المرأة في كل أطوار

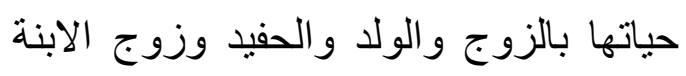


حياتهم. فهذا الكتاب خلاصة التجارب والأخطاء في ملف شامل لكل مديرة بيت حتى تنتهي مشقة الأعمال المنزلية اليومية؛ لتتظيم علم يمكن تعلمه، ومن يمكنه إمتاعنا.

\section{العلوم السباسية}

r纟

استراتيجية مواجهة التطرف: دراسة في ضوء التجربتين المصرية والاماراتية، تأليف: وليد سمير المعداوي. القاهرة: جامعة الدول العربية، المنظمة العربية

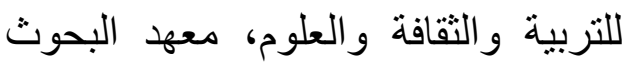

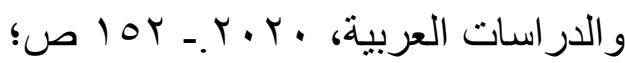
ع זسم.- (در اسات استر اتيجية ومستقبلية؛

العدد ع $\varepsilon$

qVA_qVV_0 - EY_V) - Tمك

التطرف: مفهومه ومظاهره و أشكاله،

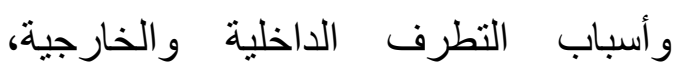
ومنهج جماعة الإخوان "نموذج للتطرف" ولتهاب

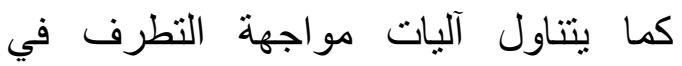
المو اثيق الدولية و الإقليمية، و النظم المقارنة، وجهود جمهورية مصر العربية في مجابهة الفكر المتطرف، و المواجهة القانونية لجرائم التطرف الإلكتروني في التشريع المصري، والأحكام الموضوعة في مواجهة جرائم التطرف الإلكتروني، و إنشاء أجهزه قانونية متخصصة في مكافحة التطرف و الإرهاب، وجهود دولة الإمارات العربية المتحدة في مكافحة التطرف، و وإنشاء مؤسسات وطنية

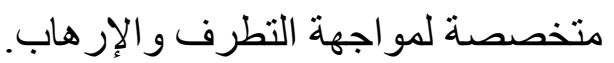

يرى البعض أنه يمكن تقسيم المجتمع القاهري في العصر المملوكي إلى طبقتين: الطبقة العسكرية، وتشمل أهل الدولة من الن الهن

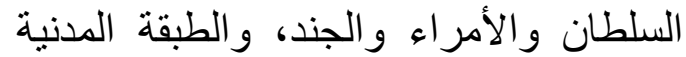

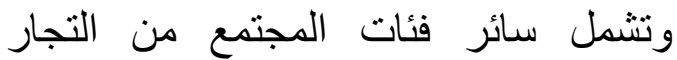

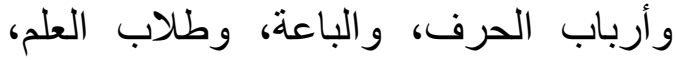

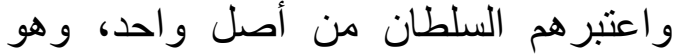
(الرعية)، وساهمت النساء و البنات و أخوات هذه الثرائح بدور كبير، ونجد أن طبقات

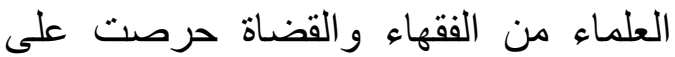
المصاهرة فيما بينهم نتيجة للمستوى الاجتماعي.

rr

وبقيت أنا المديرة!: دليل كل مديرة بيت

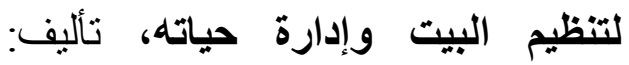
شيرين عز الدين. طا. القاهرة: مكتبة

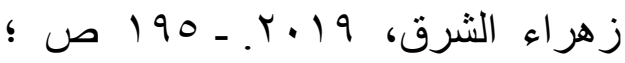

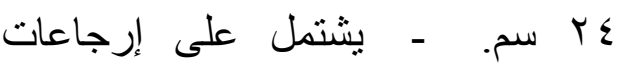

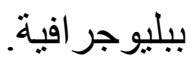

فهو نتاج خبرة سنوات من المحاولات

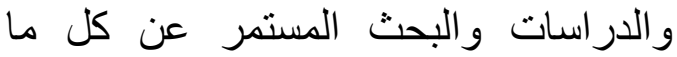
يجعل حياتنا أبسط وأسهل، لأني لم أجد المد مرجعًا واحدًا او مصدرًا موثوقًا بمكنه أن الن الن يساعدني كمديرة منزل، في كل أسئلتي غير ولير العادات أو الاعتبار ات المألوفة في بيئتنا، والتي قد لا تتقذ في كثير من الأمور. وبما

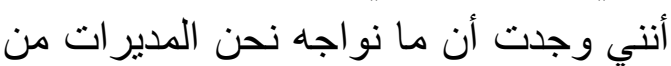

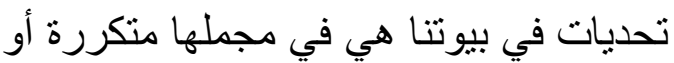

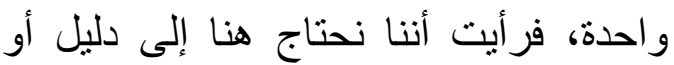
كتيب إرشادات ربما تمنى الكثيرون وجودها قبل أن يحاولوا ويفثلوا عدة مرات ريدان خلال 
وتأثيره على العلاقات بين مصر و إيران، بالإضافة إلى فصل خاص بالئل العلاقات التات الثنائية السياسية والاقتصادية و الثقافية بين البلدين

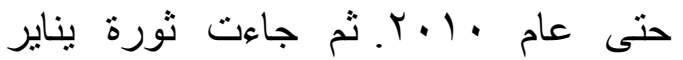

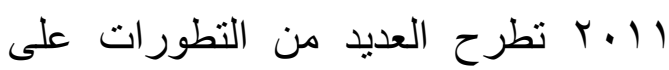
مسار العلاقات الثنائية بين مصر و إيران.

\section{العلوم الاقتصادية}

TV

الموارد البيئية الطبيعية في الوطن العربي، وقضاياها الهامة، تأليف: أحمد العدائ السروي.- طا. ـ- القاهرة: الدولية للكتب

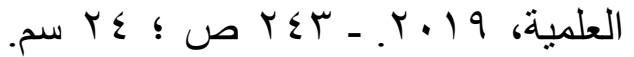
يشتمل على إرجاعات ببليوجر افية. تدمك ) IVA_qVV_AOYY_Y فكرة الكتاب تنطلق من فهم للموارد الطبيعية في الوطن العربي و وأنواعها المختلفة، مثل الموارد المائية و المعدنية و البترولية والزر اعية و النباتية و الحيو انية،

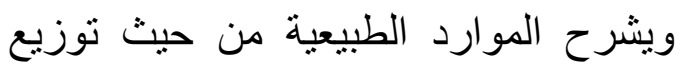
وانتشار وتوافر هذه الموارد في كل بلد

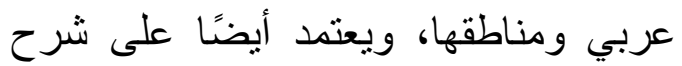
للموارد البيئية الطبيعية في وطنتا العربي على الأسلوب العلمي، وتقديم فكرة علمية جيدة عن طبيعة هذه الموارد، وكيفية الاستفادة منها، ومشكلات لضونة نضوبها

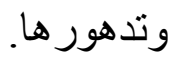

ro

الصراع على غاز شرق المتوسطوفرص التعاون، تأليف: أحمد الباسوسي.

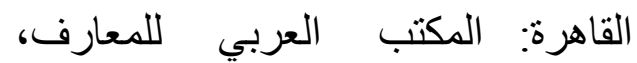
.

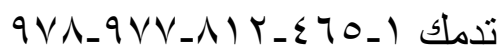

تعد منطقه حوض شرق البحر المتوسط

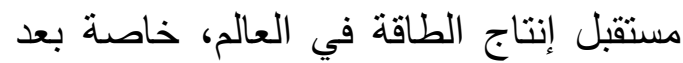
اكتشاف كميات هائلة من الغاز الطبيعي، وبلغت تقدير اته عما يزيد عن ك ا I تريليون قدم مكعب؛ مما أدى إلى تنافس كل من ئن روسيا والولايات المتحدة على تلى تلىيع دائرة نفوذهم في تللك المنطقة الملتهبة بالبترول، وتضارب المصالح بين أطر افها، ونمط تعامل كل منهم مع ملف غاز شرق

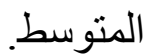

ru

العلاقات المصرية الإيرانية بعد الاحتلال

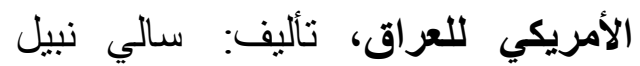

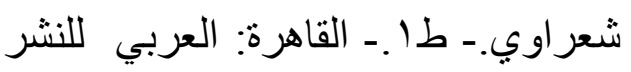

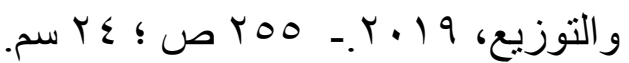
يشتمل على إرجاعات بيليوجر افية.

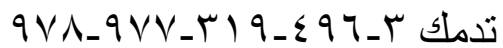
يتناول ملامح تطور العلاقات المصرية الإير انية قبل وبعد ثورة 9 و 19، و المحددات

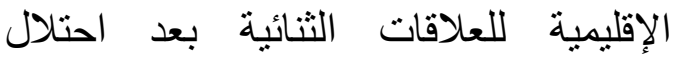

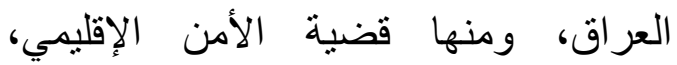
و المشروعات الأمريكية لإعادة تشكيل إقليم الإني

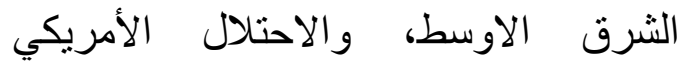
للعراق، وتطور الصراع العربي الإسرائيلي الأيكي 


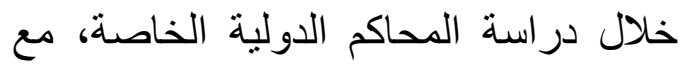
التركيز على المحكمة الخاصة بلبنان؛ للوقوف على قدرة هذه المحاكم على القضاء على ثقافة الإفلات من العقاب، وروفة هذه انتهاكات حقوق الإنسان، وتحقيق الاستقرار و الأمن الداخليين، وقد خرج الكتاب إلى أن الأن هذه المحاكم أسهمت في تحقيق العدالة الجنائية الدولية، حيث أحدثت تطورًا في

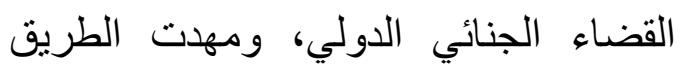

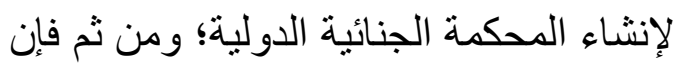

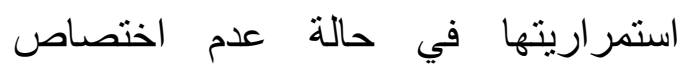
المحكمة الجنائية الدولية مطلب ملح. r.

\section{الهجرة غير القانونية: الأسباب، والاثار،}

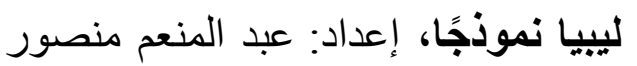

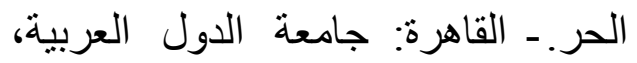

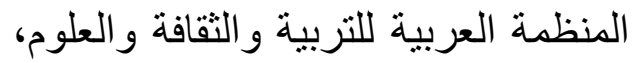

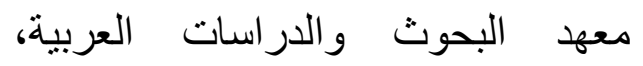
ت.

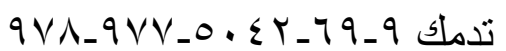

يتناول محددات الهجرة غير القانونية وأسبابها، مع مفهوم الهجرة الخارجية أو لأنيأ الدولية، و الهجرة غير القانونية و أنماطها،

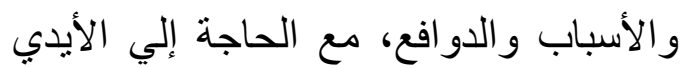

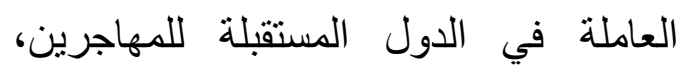
وغلق الأبواب أمام الهجرة القانونية. ونظريات الهجرة الدولية، مثل نظرية الاقتصاد الكلاسيكي - نظرية ماركس و الهجرة، ونظريه شبكة الهجرة - نظرية تخطي الحدود الدولية، نظرية التنظيم
القانون

rA

قانون التأمينات الاجتماعية والمعاشات

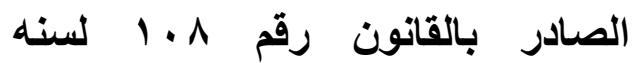

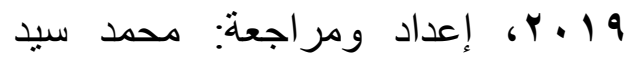

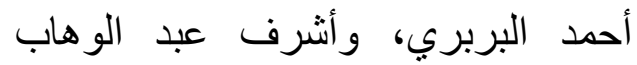

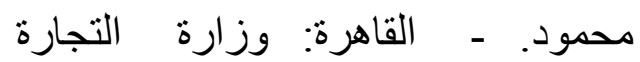
و الصناعة: الهيئة العامة لشئون المطابع

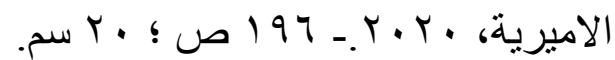
يتتاول قواعد معاملة المؤمن عليهم الذين كانوا من أفراد القوات المسلحة

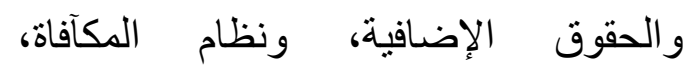

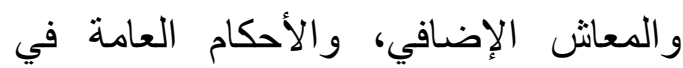
تأمين إصابات العمل، في تأمين المرض، والإن، في تأمين البطالة، في الرعاية الاجتماعية

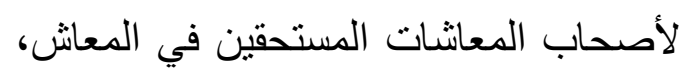

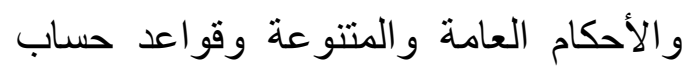

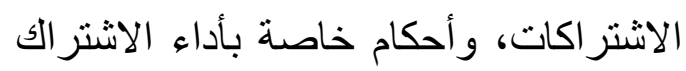

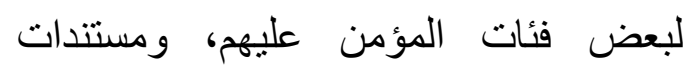
الصرف، ومواعيد تقديم طلب الصرف، ومو اعيد المناز عة، وضمانات التحصيل. rq

محكمة لبنان بين العدالة والسياسة، تأليف: سماء سليمان. - طا ـ ـ القاهرة:

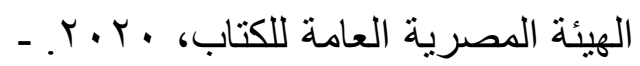

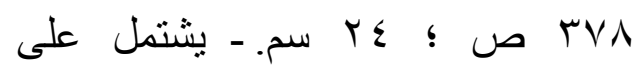
إرجاعات ببليو جر افية.

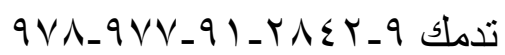
حاول الوقوف على قدرة المحاكم الدولية

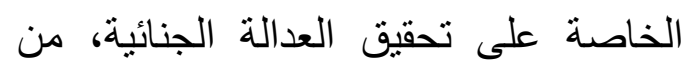


بتتاول إدارة الموارد البشرية ومفاهيمها

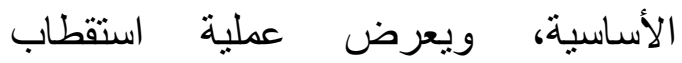
العاملين، ويذكر استر اتيجيات تدريب الموارد البشرية، و واستراتيجيات التوظيف المؤقت، ويذكر إدارة تتوع قوة العمل، ودور إدارة الموارد البشرية في بناء دعم الثقافة

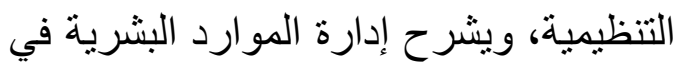
الثركات متعددة الجنسيات.

س

حروب الجيل الخامس: أساليب التفجير من الداخل على الساحة الدولية، تأليف: شادي عبد الوهاب منصور. القاهرة:

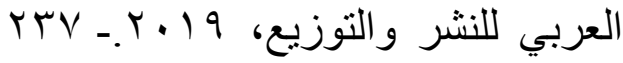
ص ؛ § سم.- (سلسلة كتب المستقبل). يشتمل على إرجاعات بيليوجر افية.

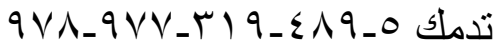
يسعى إلى شرح هذا التحول الذي شهدته الحروب من خلال تغطية المفاهيم

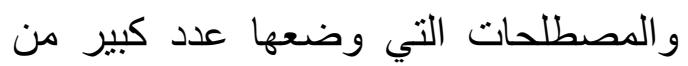

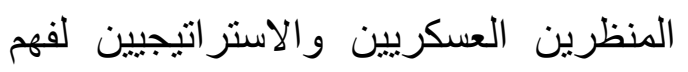
ورصد واستشراق التحولات التي طرأت على أشكال الحروب، و التي يعد من أبرزها حروب الجيل الخامس، والحروب الهجينة، والحروب غير المقيدة، وحروب القرن ولمبن

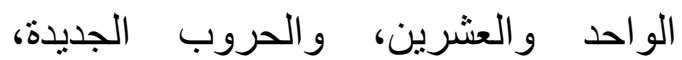
و غير ها الكثير....إخ ولخ
الاجتماعي، وتأثثر الهجرة غير القانونية على ليبيا كدولة عبور، والآثار الاجتماعية وناتيز

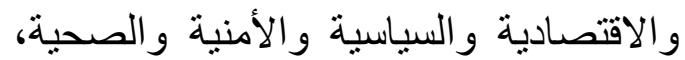

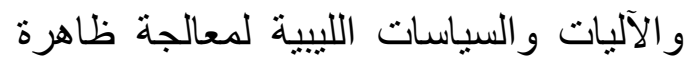
الهجرة غير القانونية.

\section{الإدارة العامة والعلوم العسكرية}

TI

الإدارة الاستراتيجية، وتأثيرها على

نجاح المنظمات، تأليف: أحمد أحمد.

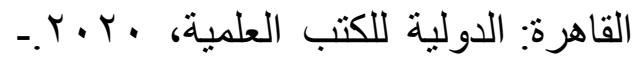

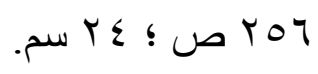

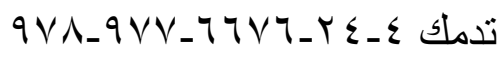

يتناول موضوع هام، وهو الإدارة

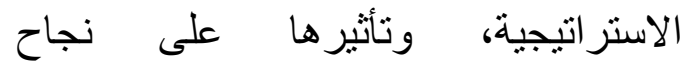

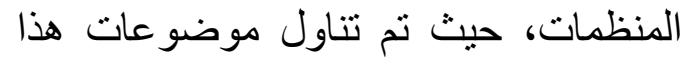
الكتاب بأسلوب علمي تطبيقي راق حديث تحققان الفرق الأساسي، وهو تبسيط مفاهيم

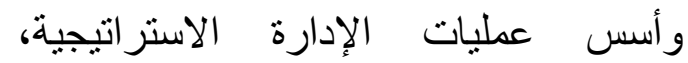

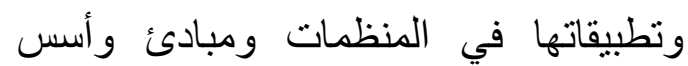

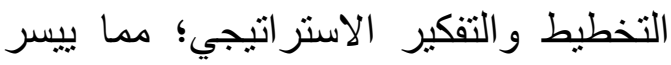
على القارئ سبل الإلمام و المعرفة بأهم نظريات وأسس ومفاهيم و أبعاد و عناصر لإلمر

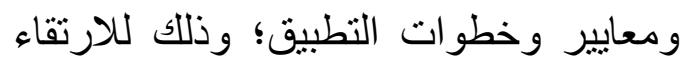
بمنظومة الإدارة.

ru

إدارة الموارد البشرية، تأليف: سيد محمد

جاد الرب. السويس: جامعة قناة السويس،

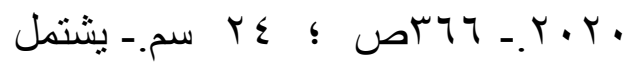
على إرجاعات ببليوجر افية. 
تعريفه اللغوي والاصطلاحي، ويعرض طرق إثبات سن الطفل الضحية، ويذكر وقت تحديد سن الطفل الضحية، ويعرض مفهوم

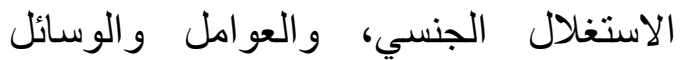
المؤدية إلى الاستغلانل الجنسي للأطفال،

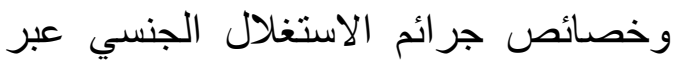

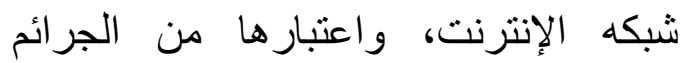

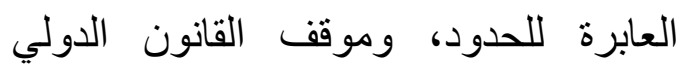
و التشريعات الوطنية منها.

ry

$$
\text { التربية والتعليم }
$$

أرض الفقراء مصر: الجامعة الأهلية، تأليف: خالد محمد أحمد. طا. القاهرة:

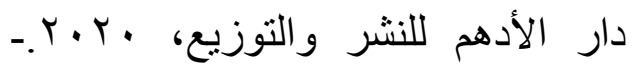

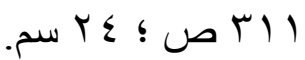

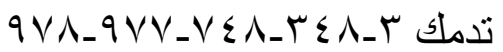
تصور متكامل لجامعة أهلية (لتعليم

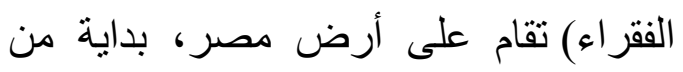

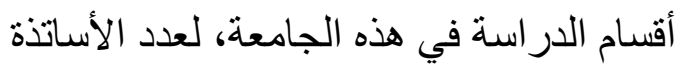

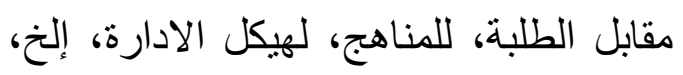

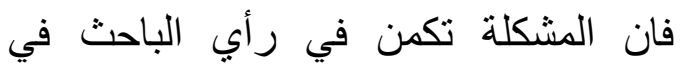
منظومة القوانين التي تعرقل مجهود أفراد المجتمع المصري لبناء الجامعة، فالتنظيم القانوني للعمل الأهلي خطوة أساسية، بدونها لئهاء سيظل هذا التصور المتكامل للجامعة الأهلية

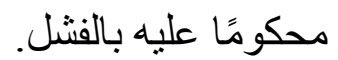
rV

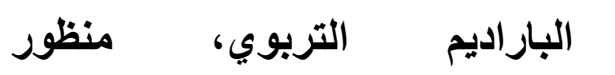

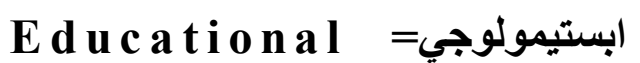
Parodigm Epistemological rร دليل الدبلوماسي المعاصر لثقافة السلم

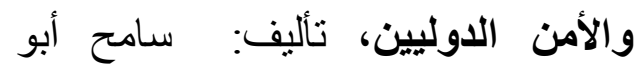
العينين. طا. الجيزة: مؤسسة بسطرون

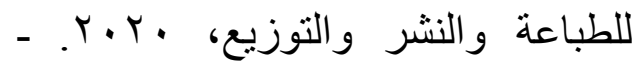
1/

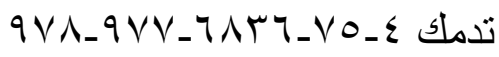
يقوم المؤلف بدور الدليل الذي يقودنا في

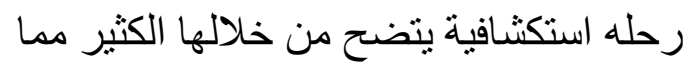
بثير التفكير و التأمل من مخاطر الأسلحة

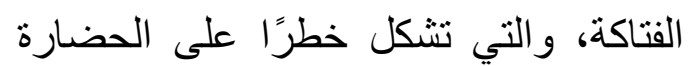
الإنسانية، ويدين المؤلف تلأك القضية الهامة لتحقيق الأمن والاستقرار على المستونين: الدولي، و الإقليمي؛ ولهذا احتلت موضو الأن عات الات

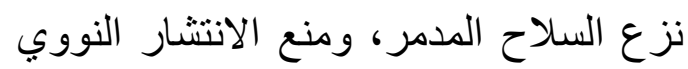

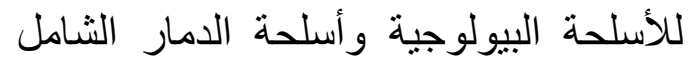
مكانة لها أهميتها في التحرك الدئولئ الدبلوماسي التماري المصري لتحقيق الأمل المنشود.

\section{الخدمة الاجتماعية}

ro

الحماية الجنائية للأطفال من الاستغلال

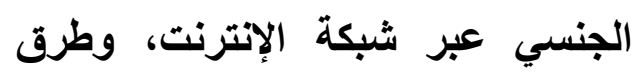
مكافحتها: دراسات مقارنة، تأليف: كريم

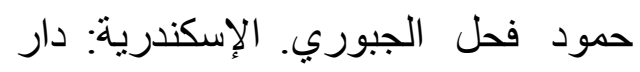

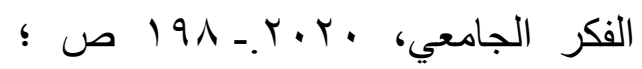

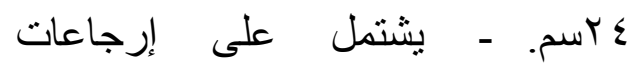

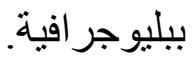
9VA_qVV_rVq_oV7_V تدمك يتناول ماهية الاستغلال الجنسي للأطفال

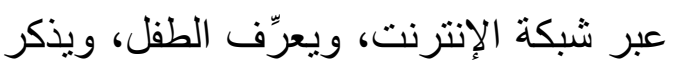




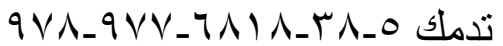
تتعرض التربية الحديثة لكثير من سوء الفهم من مريديها، و الكثير من الهجوم من

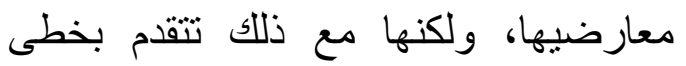

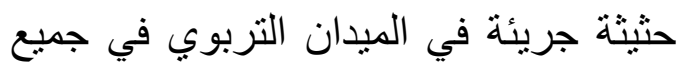
المجتمعات، وقد حاول كثير من المخلصبن فين لها أن يدافعوا عنها، كل بوسائله الخاصة، وفئه فمنهم من حاول توضيحها، و إلقاء الضوء على كثير من جو انبها دون أن بهاجم التربية القديمة، أو أن يبرز عبوبها. وهذه محاولة

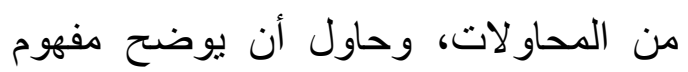
التربية الحديثة دون أن يدافع عنها، ورإنما كان هدفه أن يقول للقارىئ: هذه هي التربية الحديثة دون زخر فة أو تتميق.

rq

\section{تصميم البرامج التعليمية وفق تقتيات} التعليم، نأليف: عايدة تاوضرس مشرقى.

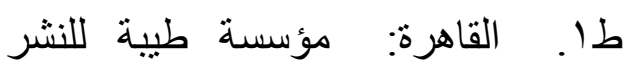

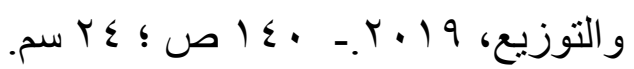
تدمك

يوضح الاستخدام الأمنل للتقنيات

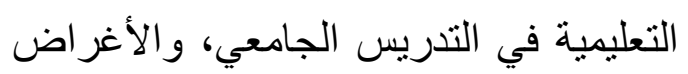
العامة للتقنيات التعليمية، ومعوقات استخدام

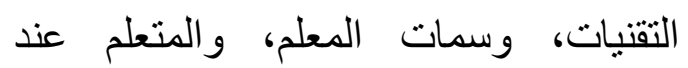
استخدام التقنيات، ومعايير نجاح إعداد التقنيات التعليمية، وخطوات الاستخدام

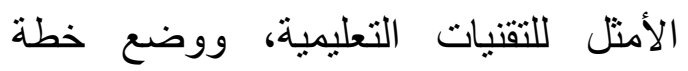
للتدريب على البرنامج، وهل أستطيع أن ودئ

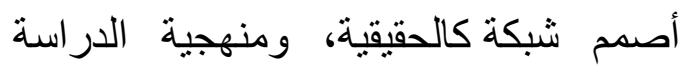

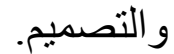

Perspective

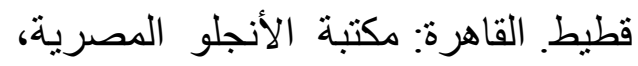

$$
\text { تدمك اr.r. }
$$

إن البار اديم التربوي الموجه للائهائية

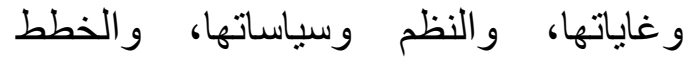

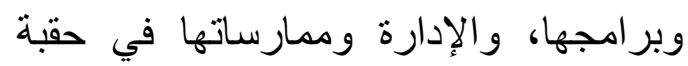

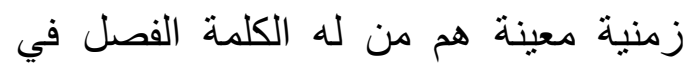

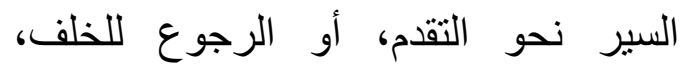
والركون للتخلف. وقد بشير المردود

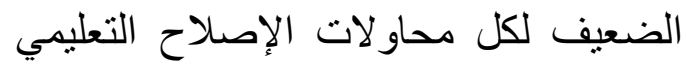

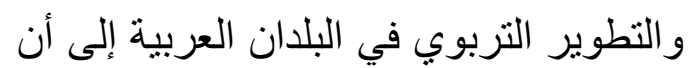
المشكلة في جذرها هي البار اديم التربوي

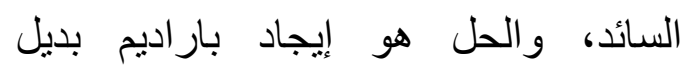
يستوعب التحو لات العلمية و المعرفية، بديل

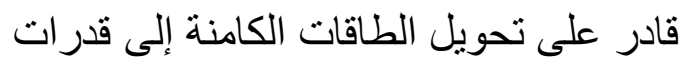

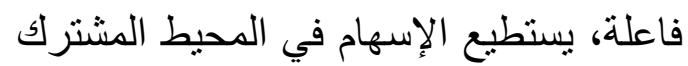

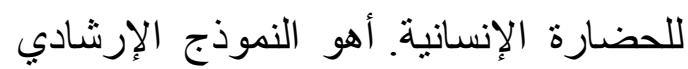
أم الإطار الفكري و المنظور المعرفي؟ وهل الإنل الفودئ

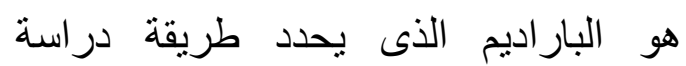
المعرفة، والأسس الفكرية كمنهج محوري للممارسات العلمية المنوافق عليها في أي تخصص من التخصصات، أو محال من

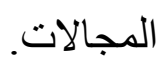

rᄉ

التربية الحديثة، تأليف: روجيه كوزينيه؛ ترجمة: محمد زيدان، وحلمي قلادة؛ مر اجعة وتقديم: محمد النجيجي، الجيزة:

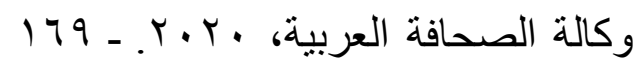
ص ؛ ( آ سم. 
المدرسية المعينة بحماية البيئة، و النشاط المدرسي ودوره في تنمية الثعور بالمسئولية الاجتماعية، ويذكر أهمية

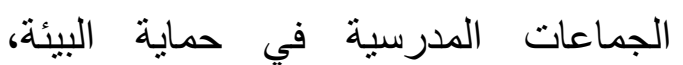
ويعرض أسس دعم المشاركة في حماية

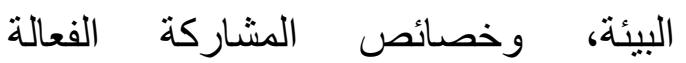
لجماعات النشاط المدرسي في حماية البيئة، ويذكر النشاط المدرسي ومفهومه، وفلسفته،

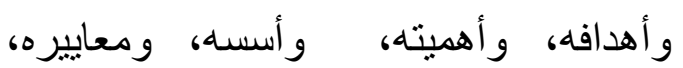

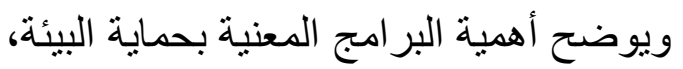

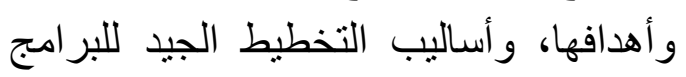
البيئية، وتتفيذه، وتقويمه.

$\varepsilon r$

الجودة ومستقبل التعليم العالي، تأليف:

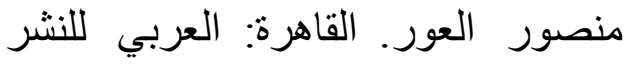

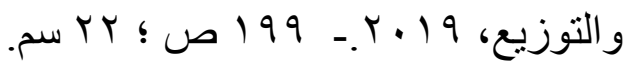

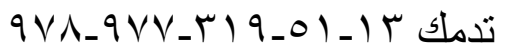
اشتمل على عدة فصول، منها الجودة في مؤسسات التعليم العالي، وأيضًا الجودة في في لهي التعليم الذكي بصورة تفصيلية تتناسب وحداثه هذا النمط الجديد من التعليم، و أيضًا مقياس العور، وهو مقياس الجودة للجامعة. قمت بصياغاته على شكل أسئلة بحيث يساعد المسئولين عن الجامعات في التعرف على موقع جامعتهم من الجودة، ومستقبل التعليم العالي... إلخ، و أيضًا يجيب مئ على على عدة أسئلة، منها ما هي طبيعة العلاقة بين الجودة وتكنولوجيا العصر. $\varepsilon$

تنمية مهارات اللغة الإنجليزية لأطفال

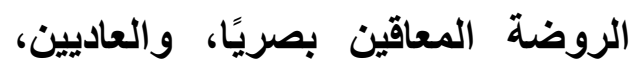
تأليف: هبة أحمد عبد الصبور لمعافين يصنا، وحمد. طا ـ القاهرة: دار الحكمة للطباعة و النشر

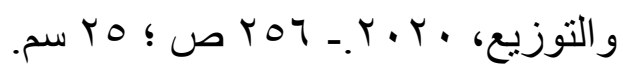

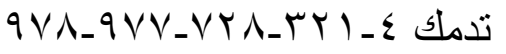

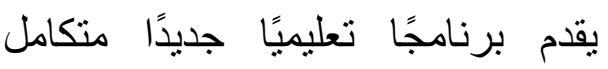
الأركان، يعتمد في تصميم أنشطته على لئل استير اتيجيات التعلم النشط التي تجعل الطفل

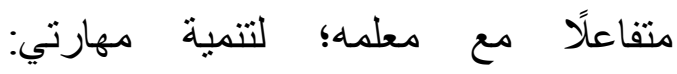
الاستماع، والتحدث باللغة الإنجليزية يمكن معن استخدامه مع الأطفال بشكل عام، والمعاقين بصريًا بشكل خاص، إضافة لكونه برنامجًا ينمي تللك المهارات بطريقة شيقة وسهلة. ويحوي أيضًا دليًا يشرح كيفية تطبيق البرنامج ليعطى أفضل النتائج، في هذي لئل

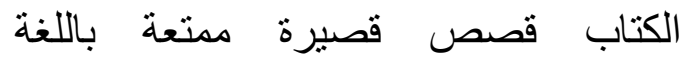
الإنجليزية وضعت داخل البرنامج لتحفيز الأطفال على ممارسة اللغة الإنجليزية. (1)

الجماعات المدرسية ودورها في حماية

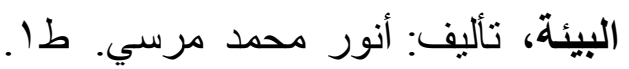

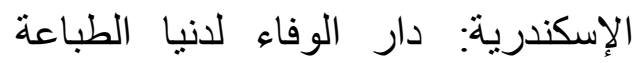

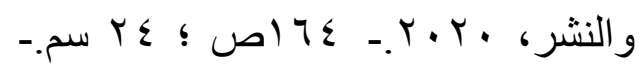
يشتمل على إرجاعات ببليوجر افية.

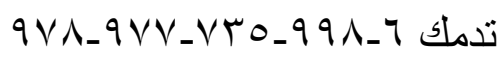
يتناول مفهوم البيئة، ويذكر دور الإخصائي الاجتماعي في تنمية إدرات الطلاب لخدمة البيئة، ويعرض الإهماعات 


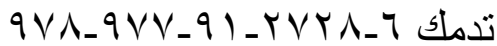

لقد استجدت تغيرات وتطورات عظيمة

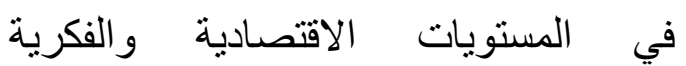
والاجتماعية للاول النامية، وعلى سبيل المثال لا الحصر دولتا إندونيسيا وماليزيا، لإنها ويرجع ذلك إلى المزيد من اهتمامهما بالعلم

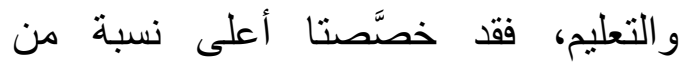

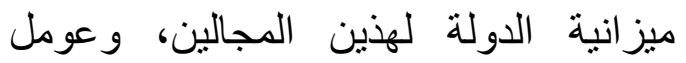

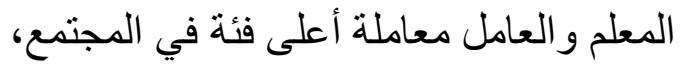
مما أعطاه كل المميزات المادية و المعنوية التي تجعله لا ينشغل عن رسالته السامية في إنشاء وتكوين جيل متحضر ومثقف، ومحب لانب لني

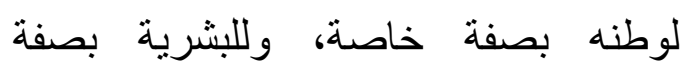
عامة.....

«o

المسرح المدرسي والمنظومة التربوية:

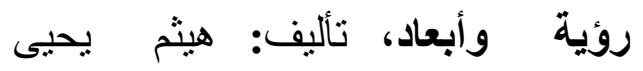
الخواجة. طا ـ الإسكندرية: مركز ليفانت

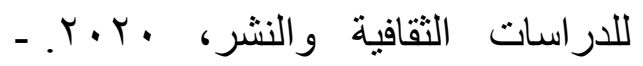

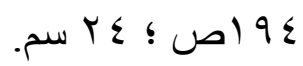
تV人_qVV_-7人) يتميز عن غيره؛ لكون مؤلفه مارس العمل في المسرح المدرسي، وخبر المسرح تأليفًا وتنظيرًا، فالكاتب بربط بئ التين التنظير و التطبيق، مؤكدًا على ضرورة التركيز على هذا المسرح في التعليم والتعلم في فوكي فئروني عصرنا الحالي، تحت مظلة المنظومة التربوية والأخلاقية، والإبداع و والابتكار و الخيال العلمي بفضاءاته المتتو عة و الملونة. $\varepsilon r$

خرافات كبرى عن التعليم والتعلم، تأليف: جيفري دي هولمز ؛ ترجمة: أحمد حمدي مصطفى. طا. القاهرة: روابط للنشر هوبر

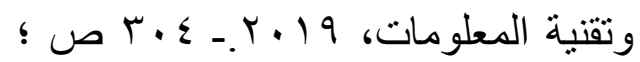
و 9VA_qVV_TVOr_q_. تدملك يركز على بعض من أكثر الخر افات أهمية وتأثثرًا في هذا المجال، مع تقديم نقيم

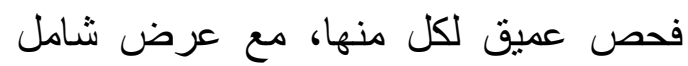

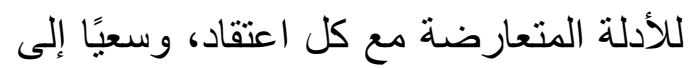

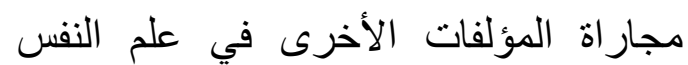
التربوي. وشملت خصائص الطلاب المتعلقة بالتعلم، ووجهات النظر حول سير عملية التعلم، وقضايا أخرى متصلة بتقنيات التعليم

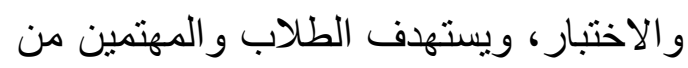

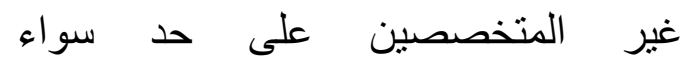

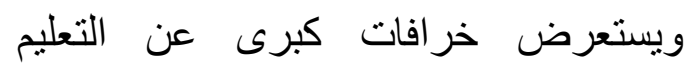
والتعلم، والبحث العلمي في عدد المفاهيم

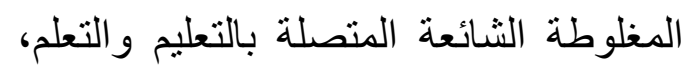

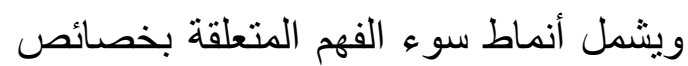
الطلاب، وكيفية تعلمهم، وصلاحية الأساليب العديدة للتقييم، و أنماط شائعة من سوء ؤعه الفهر

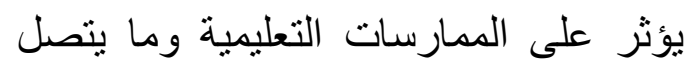

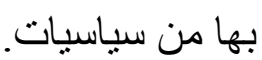
$\varepsilon \varepsilon$

العلم والتعليم بين الماضي والحاضر والمستقبل، تأليف: محمد السيد خليل. القاهرة: الهيئة المصرية العامة للكتاب،

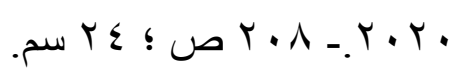


المحاضرات الافتتاحية العامة، و الجلسات العلمية، وورش العمل، و الموائد المستديرة حول المحاور المطروحة في المؤتمر، والتي التي المئي تنطلق من تقارب العلاقات وتثابكها بين العاتئ العلوم الإنسانية وبعضها البعض. وتحمل الدورة الأولى للملتقى اسم العالمة الجليلة

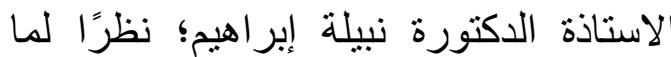
قدمته في هذا الحقل من دراسات مهمة ور ائدة.
العادات و التقاليد و القلكلور

$\leqslant 7$

الأدب الثعبي والاراسات البينية: أعمال

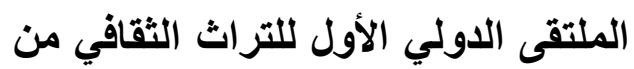

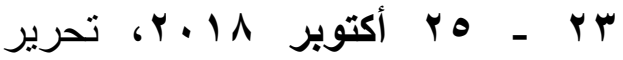
وتقديم: خالد أبو الليل. القاهرة: المركز

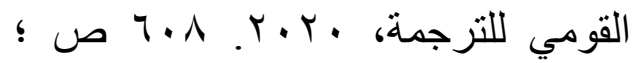

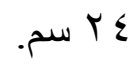
الملتقى الذي اشتمل علي عدد من

\section{ـ . . . العلوم البحتة (الطبيعية)}

النباتات الذابلة، وتنقية الحشائش، و التهوية وتشويش النباتات بالمشتل، ويعرض مجاميع

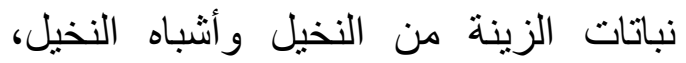

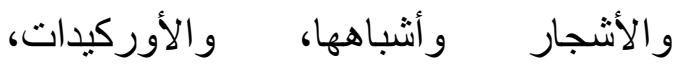
والأبصال المزهرة، ويعرض قطف وتداول الأز هار ، و العناية الخاصة بنباتات الزينة.

\section{العلوم الحيوانية}

$\varepsilon \wedge$

Avian = المناعة في الطيور جأن تأليف: جودة محمد جبريل. القاهرة: دار الفكر العربي،

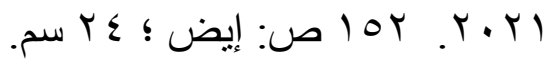

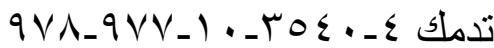
لقد ظهر علم المناعة كحلم مستقل منذ

\section{العلوم التباتية}

$\varepsilon \vee$

نباتات الزينة: الإكثار، والرعاية بالمشتل، تأليف: محمد عبد الفتاح حمزة. القاهرة: جامعة الأزهر، كلية الزربة داعة،

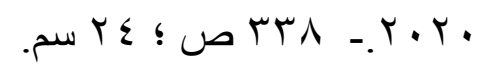

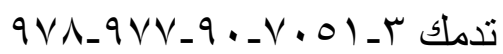
يتناول تعريف وتقسيم نباتات الزينة، ويعرض مشتل نباتات الزينة، وأقسامه،

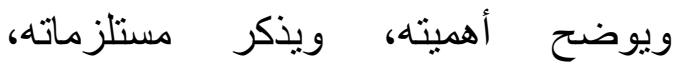
ويعرض تصميم إنشاء مشتنل الزينة وتشغيله، ويوضح الخدمة النباتية لنباتات الزينة، وجمع وتجهيز البذور، وتجهيز وبوهيل أوساط الزراعة والري، ويعرض وضه مكافحة

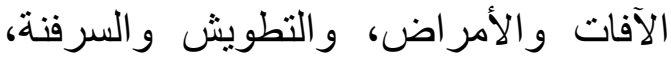
وكيفية التعليم، و التدوير ، ويشرح كيفية از الة ولة ولين 
الطيور، و إعطاء الأمصال للوقاية من هذه الأمر اض التي تتسبب في خفض المناعة، وكيفية تقوية هذه المناعة عن طريق إعطاء المضادات.
حوالي مائة وخمسين سنة، فهو يدرس المبن

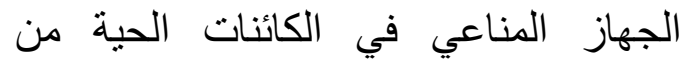
الناحية الوراثية، و التعامل مع الأعراض فئل التي تظهر على النوع الواحد من هذه النه

\section{. . . العلوم التطبيقية (التكنولوجيا)}

المسائل المتعلقة بالمرضى تحت تأثير

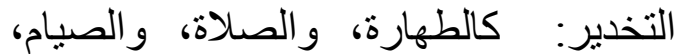
ومعرفة حكم الأقوال التي تصدر من من المريض المخدر، وما ينرتب عليها من آثار شر عية: كالإقرار ، و الطلاق و غير هما.

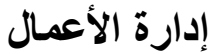

0 .

كفاءة التميز في تحليل وتثخيص المشكلات، واتخاذ القرارات، تأليف: عايدة تاوضرس مشرقي. طا ـ القاهرة:

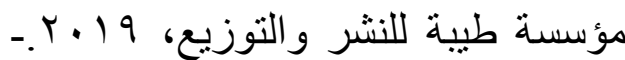

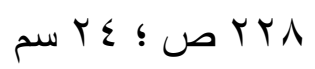

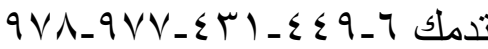

يتناول مفهوم القيادة الإدارية وأنو اعها،

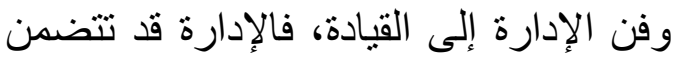

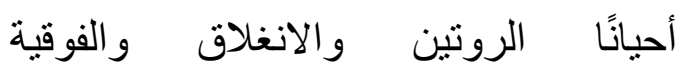

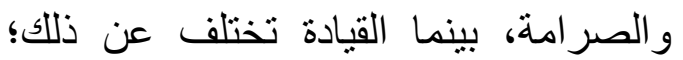
لأنها تعني إدارة البنية الهيكلية المتكاملة للمؤسسة، و التفاعل بين أقسامها و عناصر ها؛ لتحقيق الأهداف المرسومة، كما تعد عملية

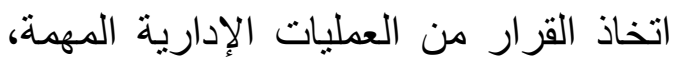

\section{العلوم الطبية}

$\leqslant 9$

التخدير الطبي في ضوء الأحكام الققهية:

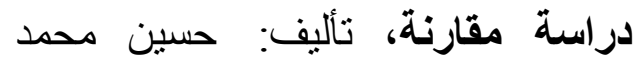
بيومي الثيخ.- طا .ـ الإسكندرية: مكتبة

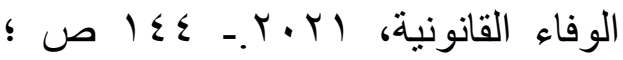

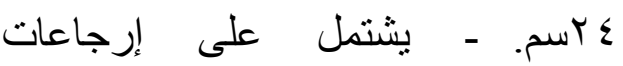

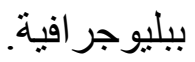

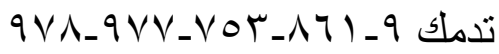
يتناول أهم وسائل الطب، خاصة في

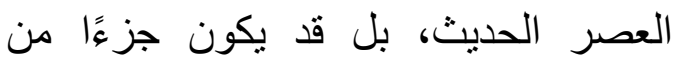
العلاج في بعض الأحيان، وقد أناح المجال

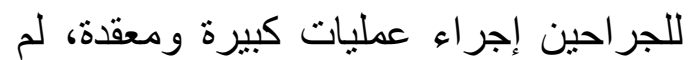
يكن من الممكن أبدًا اجراؤها قبل التوصل إلى التخدير الطبي، ولما كان التخدير ضروريًا، وأصبح من الأساسيات اللازمة في كل عمل طبي، يتناول الكتاب أيضًا طبيعة التحدير، وما له من آثار سلبية على لئى لهي

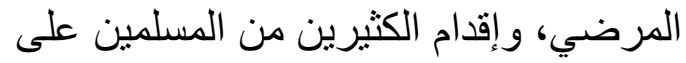
العمليات الجراحية غير الضرورية لها،

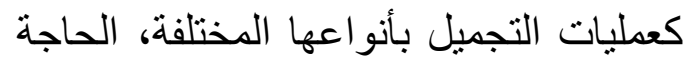
إلي معرفة الرأي الفقهي في كثير من بن اعنيات 
الأزمات لهم، طالبة دعم كل فرد منهم، وعليها أن تدرب العاملين معها لاختبار

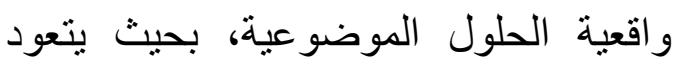
العاملون على التعامل مع الأزمات.
كما يتناول تحليل وتشخيص المشكلات في

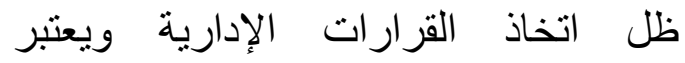
التخطيط متطلبًا أساسيا في عملية إدارة الأزمة، فيجب على القيادة التوجه مباشرة إلى العاملين مع مؤسساتهم، وتقديم خطة

\section{القنون الجميلة V. .}

و الكيميائية، ويعرض كيفية إنتاج حديد

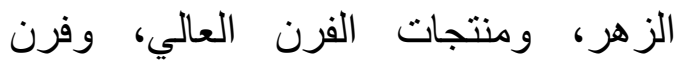

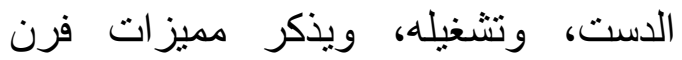

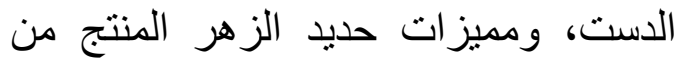

فرن الدست، وإنتاج الحديد المطاوع، وفرن

التقليب، ويذكر استعمالات الحديد المطاوع

و إنتاج الصلب، وطرق إنتاجه، ويذكر الحدادة البدوية، وتشكيل المعادن بالحدادة وطئ

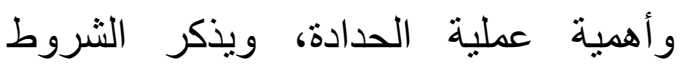
الو اجب تو افر ها في المعادن القابلة للطرق.

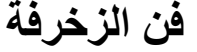

01

الحدادة اليدوية والآلية وفن زخرفة

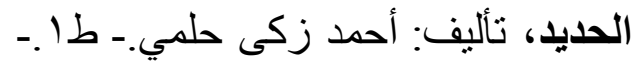

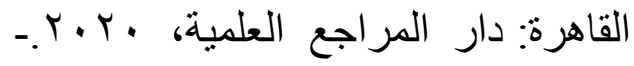
ت 9VA_9VV_70V) _. تدمك I يتناول استخلاص و وإنتاج المعادن الحديدية، والمواد المركبة والمساعدة، وخو اص المعادن، و والخواص الفيزيائية

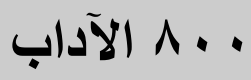

غرائب بيته وخشونته عن كل ما سبقه. يتضمن الكتاب خمسة فصول، هي در اسات لنصوص سردية قصصية وروائية لخمسة لئة لرنية أصوات للتميز والتفرد في عالم الإبداع السردي ما بعد الحداثي، وهم الأستاذ

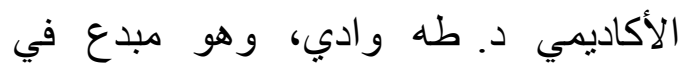
القصة القصيرة و الرواية والمقالات النقدية ولدية

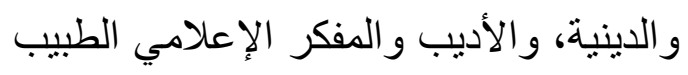

$$
\text { الأدب العربي - تاريخ ونقد }
$$

or

جماليات سرد ما بعد الحداثة، تأليف: أميمه عبد الرحمن. - القاهرة: مكتبة

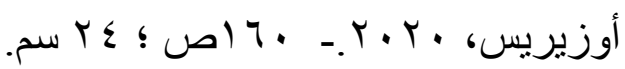
تدمك +. 1 . يناقش أساسًا ما بعد الحداثة، في لون من المحاكاة الساخرة لذاته، فيعكس و اقعًا في لئ لئ 
07

بشويش: شعر العامية، تنألبف: عاطف عبد الحمبد. - طا. ـ الجيزة: مؤسسة يسطرون للطباعة و النشر و التوزيع،

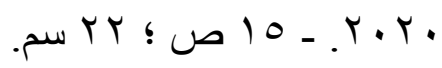
qVA_qVV_ ov

تحفة عكازين: شعر، تأليف: سامح القصبي.- طا .- بنها: دار فهرس للطباعة

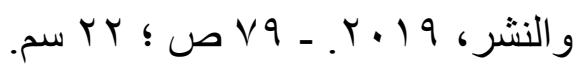

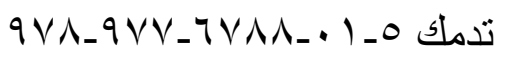

$0 \wedge$

تلاوة كتاب السامري، تنأليف: محمد مجدي.- طץ.- بنها: دار فهرس للطباعة

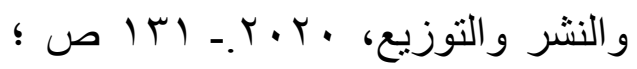
r r سم.

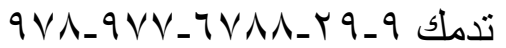
09

ديوان أشعة وظلال، تأليف: أحمد زكى أبو شادي. القاهرة: شركة نوابغ الفكر

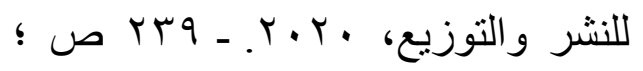
ع بـ تخملك 7 .

رسائل أرضية للرب: شعر، تناليف: آية حكيم.- طا .- بنها: دار فهرس للطباعة

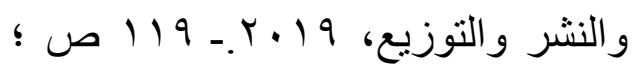

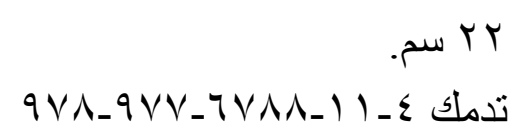

النفسي د. محمد المخزنجي، وقد تخصص في كتاباته السردية في فن القصة القصبرة، و الأديب و الكاتب الصحفي خيري شلبي، صاحب الروح الساخرة في الحياة، وله تجارب عن المهمشين، و الكاتب الروائي و القصصي محمد البساطي، وهو محاسب ويتميز بدقة الكتابة، و الكاتب صنع الله إبر اهيم، ورواية (ذات)، وفيها يزاوج بين السردي و الإخباري.

\section{الثثعر العزبي}

or

أراقب رامبرانت، ثم أصغي إلى زوال الأثياء، تأليف: سراج الدين الورفلي.طا ــ الجيزة: مؤسسة بسطرون للطباعة

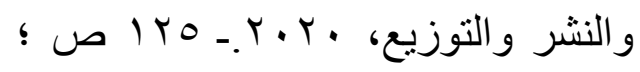

$$
\text { تدمك rr. }
$$

oร

أوراق من زمن العزبة، تأليف: سيد عبد

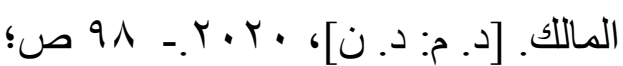

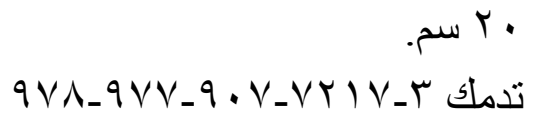
00

بتشبه لي: أشعار بالعامية المصرية، تأليف: محمود السيد.- طا .ـ- القاهرة: دار

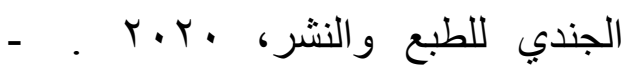
. (ص ؛ تدملك • ت 
77

قطفة عسل، تأليف: هانم عبد اللطيف. القاهرة: مطبعة نسائم للطباعة والنشر هان

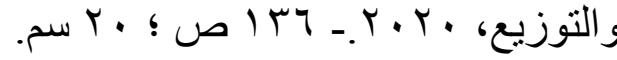
$7 \mathrm{~V}$

لا أرى جسدي: شعر، تأليف: عمار علي

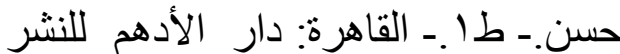

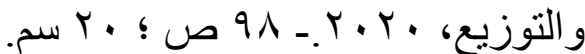
تدمك ع 71

ם منهك كأنه المعجزة، تأليف: مروة أبو

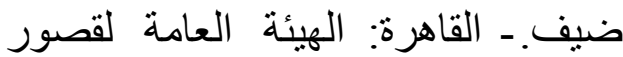
99

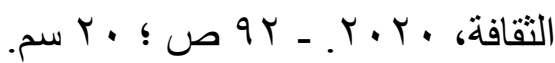

مواقيث أبي، تأليف: عثم الثيمي. القاهرة: الهيئة العامة لقصور لـالية التقافة، ( $9 \vee \wedge$ _ $9 \vee V-9 Y$ - IV $\mathrm{V} \cdot$

موت لا يقرأ الخريطة، تأليف: إيهاب الر افذ. القاهرة: الهيئة العامة لقصور

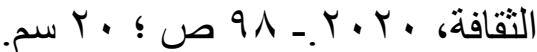
V)

ميت على قيد الحياة، تأليف: سامح هريدي. \}.د. مج\{: دار الكنزي للنشر

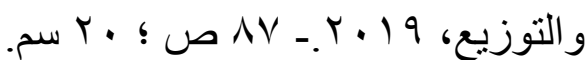
VY

نقوش: شعر، تأليف: عاطف بركات.

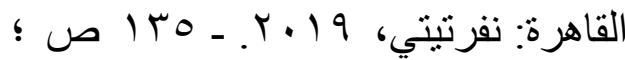

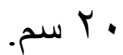

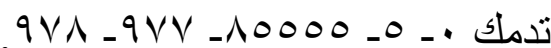

7)

صنايعي الشعر: شعر عامية، تأليف:

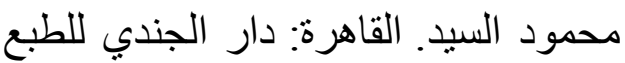

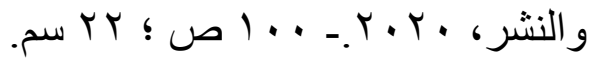
تدمك

Tr

صهاريج السراب: شعر، تأليف: طه على

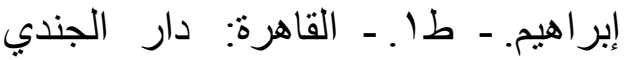

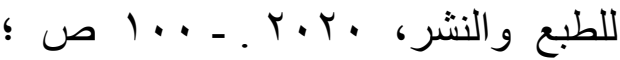

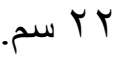

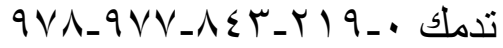

7

صوت الحلم: شعر عامية، تألبف: محمد مصطفى المرجاوي.- طا .ـ القاهرة: دار

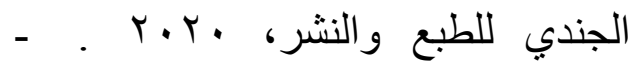

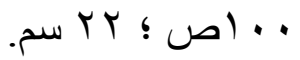
تدمك r $7 \varepsilon$

عاشق بفتيل في رأسه: شعر، تأليف: عمرو عادل.- طا .- القاهرة: دار الأدهم

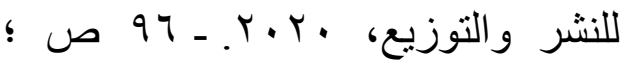
تدمك 70

عينيك لحظة صدق، تأليف: إبراهيم حجاج.- طا .- الجيزة: يسطرون للطباعة

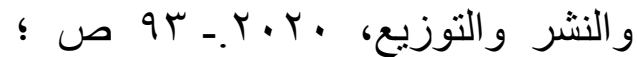

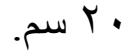

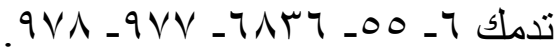


المسرحيات العربية

VT

تجارب نوعية: مسرحيات، تأليف:

نسرين نور. القاهرة: الهيئة العامة

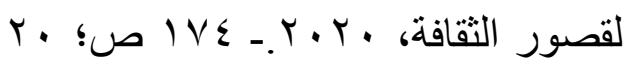
سم.- (سلسلة نصوص مسرحية 110) (1).

المسرحيات العربية ـ تاريخ ونقد

V

إثكالية الخـاتمـة في مسرح توفيق الحكيم، تأليف: علي خليفة.-- طا .الإسكندريـة: دار الوفاء لدنيا الطباعة عالية

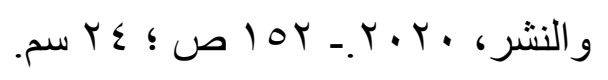$$
\text { تدمك . - } 9 V \Lambda \text { _ } 9 V V \text { _VYO _ }
$$

الخاتمة هي أهم جزء في المسرحية،

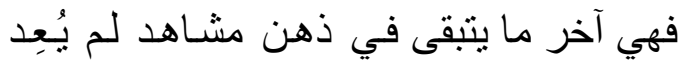

مشاهدتها، وبقدر جودنها تبقى في في ذهنه فئه

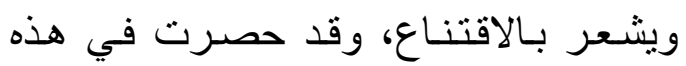

الاراسة النقاط الآتية: أولًا الخـاتمـة التي

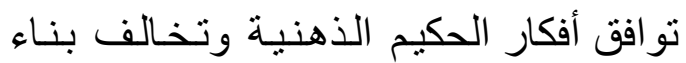

المسرحية، وقد وجدت خمس مسرحيات الفيات

للحكيم نهايتها غير محكمة، وهي: مسرحية

أهل الكهف، ومسرحية شهرز اد، ومسرحية وهية الملك أوديب، ومسرحية النائبة المحترمدة، ومنية ومسرحية شمس النهار.
Vr

يا أم الحنان، حكايات، تنأليف: إبراهيم

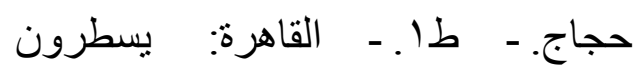

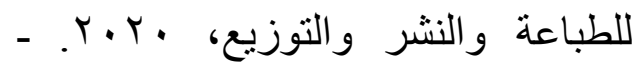

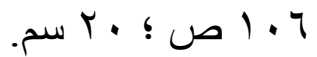

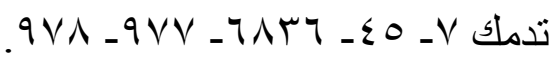
$v \varepsilon$

يمشي كأنه يتذكر: شعر، تأليف: البهاء

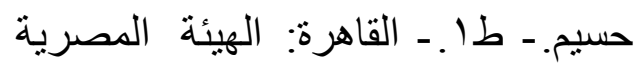

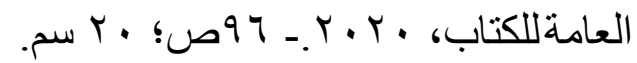

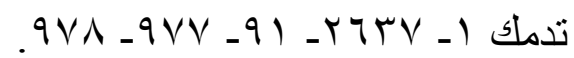
الشعر العربي - تاريخ وفقه vo

استراتيجيات النقا الشعري: مداخل نظرية، وقراءات تطبيقية، نأليف: أحمد فؤاد. - طا. ـ ـ القاهرة: مكتبة الآداب، . تدمك r يجد القارئ في هذا الكتاب قراءة جادة تعينه على قر اءة النص الثعري وتذوقه، كما يناقش وييرهن ويفند الحجج والأدلة، بعيدًا عن الأهواء و الميول الذاتية، ففي كل فصل به ما يكفي من التوضيحات، و الخلاصات،

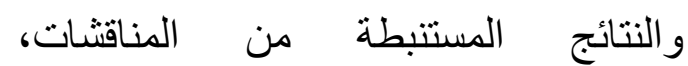
و التحليلات، وتتبع أهمية الكتاب في قراءاته لئه المنتمية لميدان من ميادين النقد الأدبي المشهورة. 
$\Delta r$

القصص العربية

ـكايات الحب والوجع وأشياء أخرى، تأليف: حسني خضر. - طا. ـ - القاهرة:

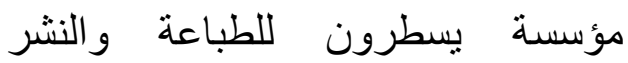

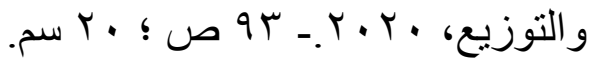
تدمك 0 $\wedge \varepsilon$

خائفًا يترقب، تأليف: رضا الحمد.- طا .-

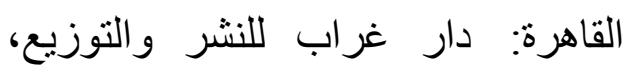
19

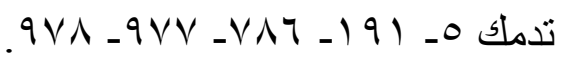
10

ذوبان الثلوج: رواية، تأليف: إيليا

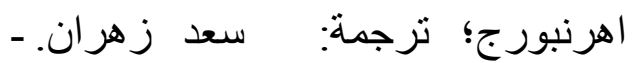
القاهرة: مركز المحروسة ل للنشر و الخدمات الصحفية و المعلومات،

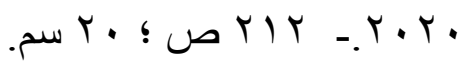

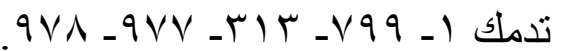
人T

الزائر رقم 9 1، تأليف: أمل صلاح.-

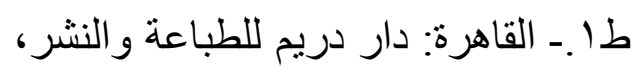

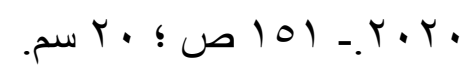
. $9 \vee \wedge-9 \vee V-7 \vee 9 \varepsilon-\varepsilon V$ - تدمك

$\Lambda V$

زوجة من العالم السفلي: رواية، تأليف:

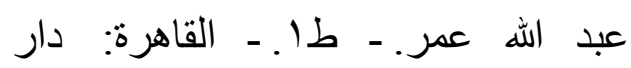

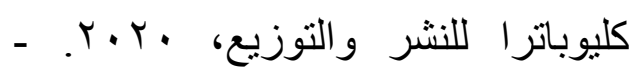

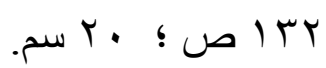

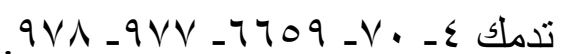

$\vee \wedge$

أحلام مصرية: مجموعة قصصية،

تأليف: مجدي علما. - الجيزة: مؤسسة مجية

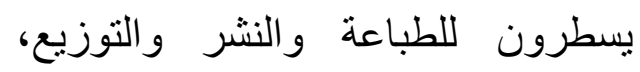

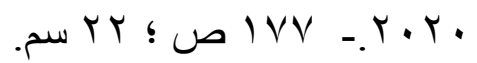

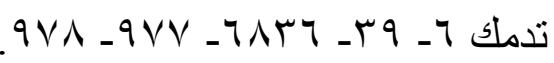
v9

إثراقة عثق: رواية، تأليف: حسن خليل، ورضوى جاويش. طا . القاهرة:

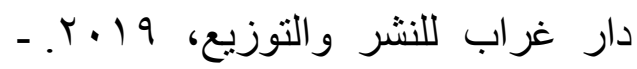
. 7 ص ؛ • بـ سم.

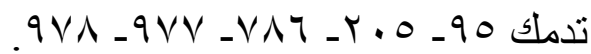
$\wedge$.

أكروميجالي: نقطة تحول، تأليف: أسماء

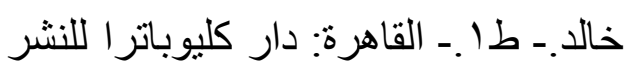

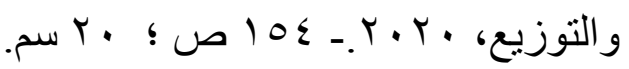
تدملك I 人)

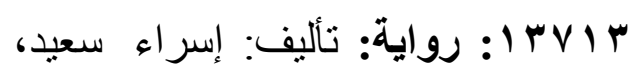
وولاء عادل عبد الوكيل.- طا .ـ القاهرة:

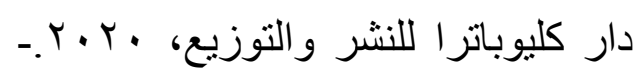

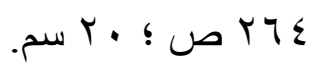

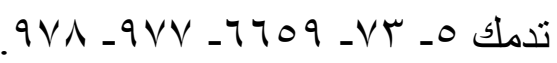
AT الحزن طقل نـائم: قصص، تأليف: محمد

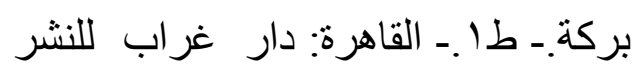

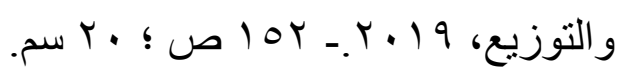
تدمك 


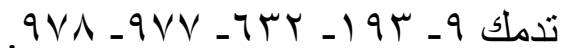

$q \leqslant$

عقدة مدريد: روايةة، تأليف: سميرة عربي. - طا. - القاهرة: دار كليوباترا للنشر و التوزيع.- ؟ • ب ص ؛ . • سم. 90

فاك النور، تنأليف: فكري عمر.- القاهرة: الهبئة العامة لقصور الثقافة، . . . ...

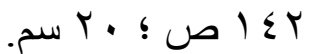
.9V人 - تدمك 97

ـ قتيلة كامب شيراز: رواية، تأليف: وسام

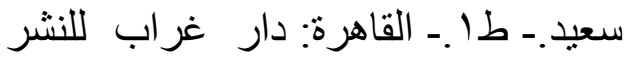

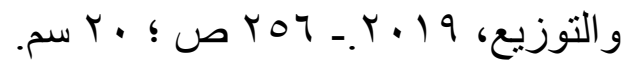

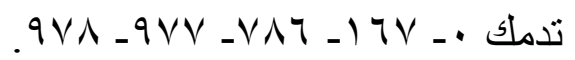
$9 V$

قلب الأسد، تأليف: بعقوب صروف.-

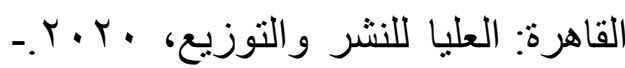
rr تدملك -9V1 - ت $q \wedge$

ם كراسة خضراء ورسائل، تأليف: حنان كمال. - الإسكندرية: دار العين للنشر، •

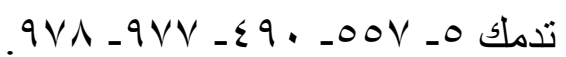
99

الكوبري الخشب، تأليف: باسر الروبي.طا ــ القاهرة: مؤسسة طيوف (يسطرون)

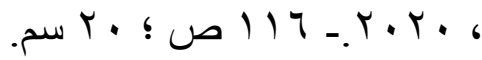
. $9 \vee \wedge$ - تحمك $\wedge \wedge$

شارع قشتمر: رواية، تأليف: وفية IV

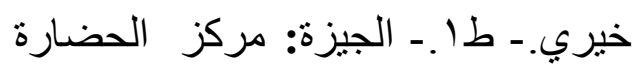

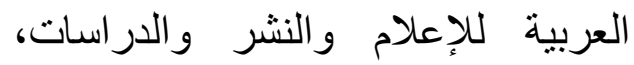

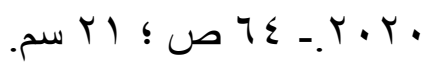

$$
\begin{aligned}
& \text { تدمك ع- } 9 V \wedge \text { - } 9 V Y \text { - }
\end{aligned}
$$

19

سيزيف بعود دائمًا، تأليف: مروة عاطف. القاهرة: الهيئة العامة لقصور الثقافة،

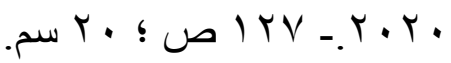
تدمك . . 9.

هؤون عائلية: قصص قصيرة، تأليف: السيد زرد. - ـ طا. - ـ القاهرة: الهيئة الهيئة

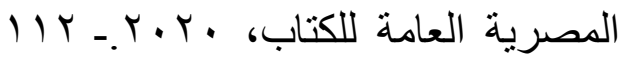

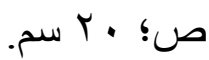
تدمك 9)

شوق: قصص قصيرة، تأليف: طاهر

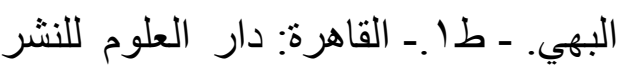

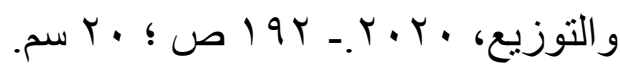
تدمك r 94

شئنا وشاء: رواية، تأليف: مهند عوني.-

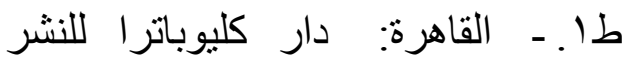

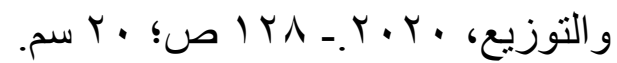
تدمك 94

ه طيف على جار الثجج، تأليف: هند فؤاد.-

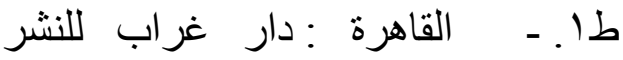

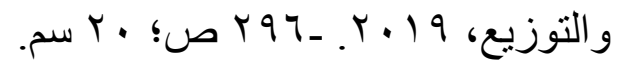


يتناول أربعة من القصاصين

المعاصرين: ثلاثة منهم مصريون، و الرابعة مغربية، عبر هذه الأعمال: رواية (أولاد حارتنا)، للأديب الثهير

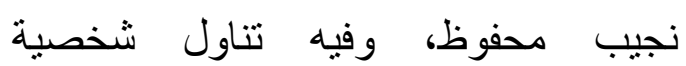
الجبلاوي الجد الأعلى للأجيال المتعاقبة. رواية (كبؤة حاحا)، للكاتبة المغربية مليكة رتنان، وتتاولت فيه قصة الفارسة زاينة الحاحي التي كانت مضرب وناب المثل في الشجاعة و الجمال و الإقدًام. رواية (سهام غير شاردة) ، للأديب

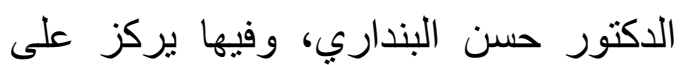
القيم الإنسانية الوطنية العليا في الفترة

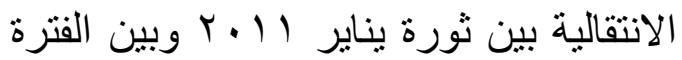
الحالية. مجموعة قصية بعنوان: ( للاخان

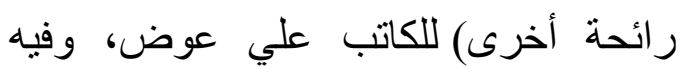
انتقت النهج ذاته من رصد للقيم الإنسانية في المجموعة القصصية، وتلمس للأبعاد الجمالية.

$$
\text { النثر العربي }
$$

1.0

a نصوص مبعثرة، تأليف: هبة السهيت.-

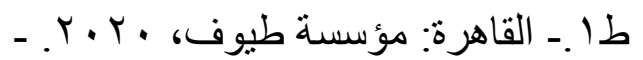

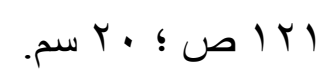
تدمك rنصوص مبعثرة، خليط من الاكتئاب والحب، خليط من العربية و والدارجة المغربية.
$1 \ldots$

لم أعد صغيرًا: رواية، تأليف: مي عصام

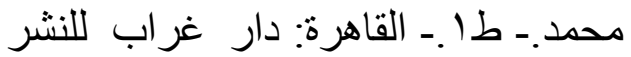

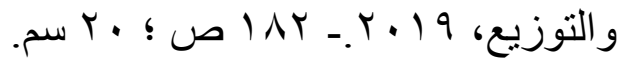

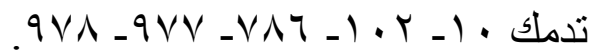

1.1

ما بعد الفراق: رواية، تأليف: أحمد سليم.-

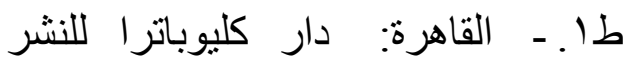

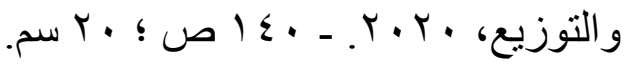
تدمك I $1 \cdot r$

الهروب من الطريق الادًائري: تسجيلات دانتي، تأليف: كريم كيلاني. - القاهرة: مركز المحروسة للنشر و والخدمات

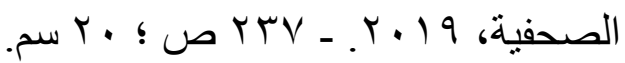
تدمك 0ـ $1 \cdot r$

وتكلم البحر: مجموعة قصصية، تأليف:

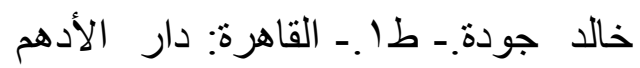

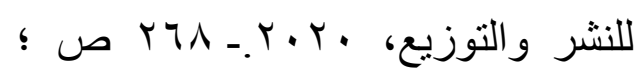

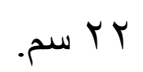
تدمك $9 \vee \wedge$ -

\section{القصص العربية ـ تاريخ ونقد} $1 \cdot \varepsilon$

قيم إنسانية وجمالية في الفن القصصي المعاصر، تأليف: عزة محمد أبو النجا.-

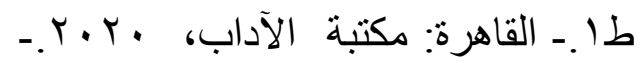
ت تدمك 
. تدمك

$$
\text { آدَاب اللغات الأخرى }
$$

111

الألفية في بلجراد: رواية من الصرب، تأليف: تايف فلاديمير بيستالو؛ ترجمة: هند عادل. - القاهرة: العربي للنشر

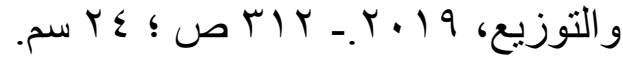
114

ـ تاريخ آل روماتوف، تأليف: سليم قبعين.طا. ـ القاهرة: العليا للنشر و التوزيع، • تدمك ع - $9 \vee 1$ -

111

تقيدة الأغنياء، تأليف: ماريا تاسلر ترجمة: ليلي البدري. - القاهرة: العربي

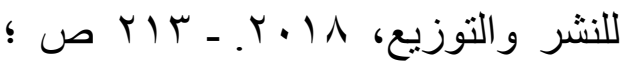
צ تدملك $11 \varepsilon$

القرصان الأيسلندي، تأليف: جون ضار؛ ترجمة: ياسمين مصطفى. - القاهرة: العربي للنشر و التوزيع، وبك. (r) تدملك 110

معسكرات الثيطان: رواية من التشيك، تأليف: ياضم توبول؛ ترجمة: عرو شطوري ـ - القاهرة : العربي للنشر

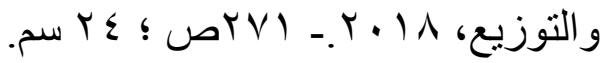

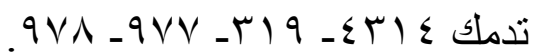

\section{القصص الإنجليزية}

$1 \cdot 7$

ألواح موسى، تأليف: توماس مان؛ ترجمة: عماد منصور .- طا ــ القاهرة:

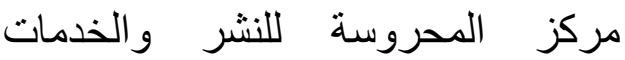

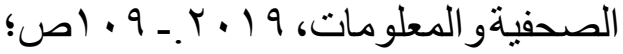

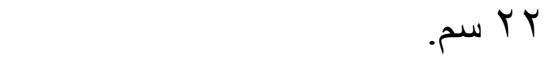

تدملك + . I. V

أوزما أميزة أوزال، تأليف: فرانك باوم، رسوم: جون أر.نيل، ترجمة: طه عبد المنعم. القاهرة: مركز جون المحروسة للنشر و الخدمات الصحفية و المعلو مات، 9 1 ـ ب .ـ וTr qV人 _

$1 \cdot \Lambda$

الثـاردة، تأليف: جون جالسوردي؛ ترجمة: إبراهيم عبد القادر المازني. طا.

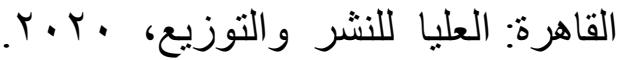

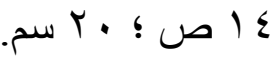
.9V人 -9VV_779 E - تدمك - 1.9

ك كيف ثكسب الأصدقاء وثوئز في الناس، تألبف: دبل كارنبجي، ترجمة: عبد المنعم محمد الزيادي. القاهرة: العليا للنثر لئر

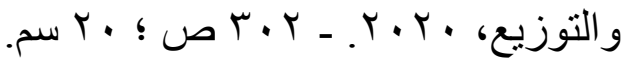
تدملك

\section{القصص الألمانية}

11

ם حم أغسطس، تأليف: بيار كوناري ؛

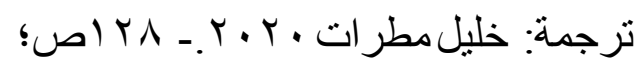

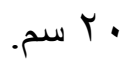




\section{. . . التاريخ، والجغرافيا، والآثار، والتراجم.}

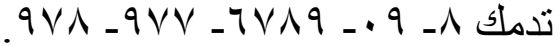

$$
\begin{aligned}
& \text { إن موقعها الوسطي (بين المحيطين)، أو }
\end{aligned}
$$

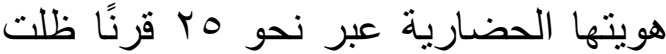
من الزمان، إلى أن حكم المصريون أنفسهر لأول مرة منتصف رن خمسينيات القرن العشرين.. من دون تدخلات أجنبية، لعشر

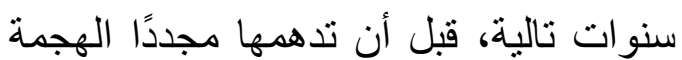

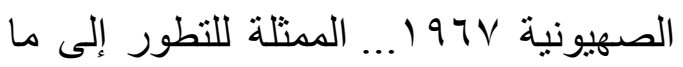
بعد الإمبريالية، تستهدف الأرض والمياه وتفكلك الهوية المصرية- ربما إلى عناصر ها لإنها الأولية قبل أن تنشر لها السمات المصرية في فلاسفة الإغريق أو فقهاء المتصوفة

$$
\text { العرب... إلخ. }
$$

\section{التر اجم والأنساب}

111

\section{أشهر مشاهير الموسيقى الغريبة قديمًا}

وحديثًا، تأليف: محمود أحمد الحفني.

الجيزة: وكالة الصحافة العربية، • • •.Y.-

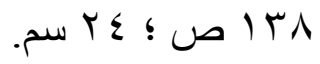

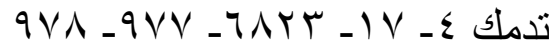

يتناول الجمع بين سيرة مشاهير العمر

القديم، ومشاهير العصر الحديث، لمعرفة الفرق بين تقدم الثعوب الأوربية على مدى ولى الثين الأيام، فقد أوجد قدماء المصريين المزمار لهاب و الصفارة واليد للتصفيق إلى الآن، ولكن

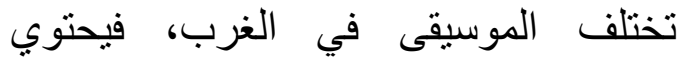

\section{الجغر افيا العامة}

117

إفريقيا: الحاضر و والمستقبل، تأليف: فاسيلي ميخايلوفتش ؛ ترجمة: ممدوح سيد مصطفى عزمي. - طا. - القاهرة:

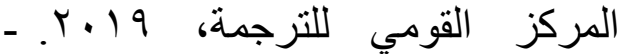
ع تدملك A- .

يتناول قضايا التنمية الاجتماعية و الاقتصادية و السياسية المعاصرة في إفريقيا ككل، وأقاليم وبلدان القارة على حدة، وأفرد

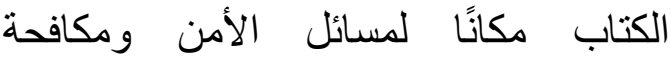
القرصنة، ودراسة حالات النزاع، وخاصة في الصومال والسودان، وطرق ووسائل تسويتها. و أولى المؤلف اهتمامًا خاصنًا بطابع وني تأثير العمل الخارجي على العمليات الجارية في القارة جنوبي الصحراء، وتبيان جوهر سياسة اللاعبين العالمبين الرئيسين، بما فيهم الولايات المتحدة و الدول الأوربية والصين لهين لهين لهين و غيرها من البلدًان. كما يلقي الضوء على لئ الاتجاهات الأساسية لتنمية التعاون بين روسيا و إفريقيا.

$11 \mathrm{~V}$

\section{مصر بين محيطين، وسطية الجغرافيا}

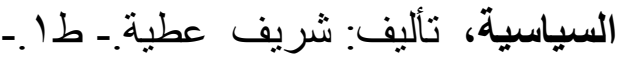

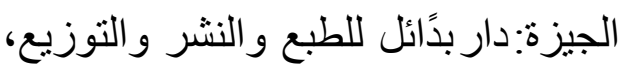
• 
$1 T$.

سعاد حسني بخط ياها، تأليف: ولاء

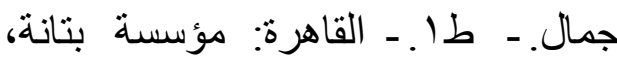

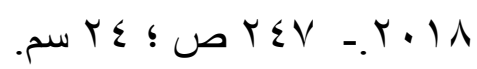

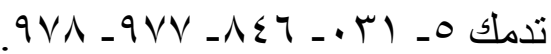

(رحلت السندريلا تاركة حالة من الحنين

الجارف لكل ما ترمز إلبه بنت البلد

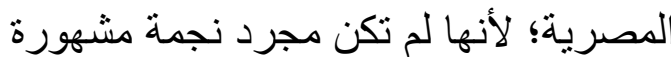

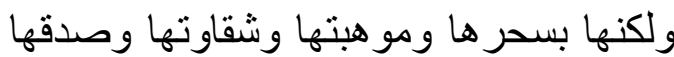

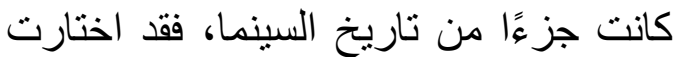
سعاد حسني العزلة بعد المرح، والاكتئاب بعد الفرح؛ بسبب السمنة المفرطة التي

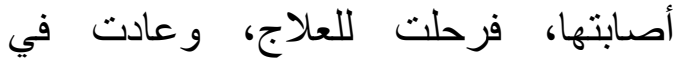
تابوت، ورغابت عنا شمس السندريلا في لحظة غروب حزينة كسرت بداخلنا قطعة من قلبنا).

$|Y|$

ـ شهود على التاريخ، تأليف: ماهر مقلد.-

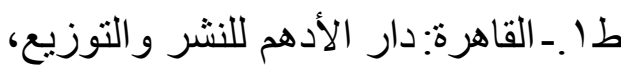

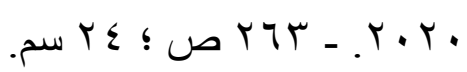

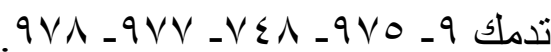

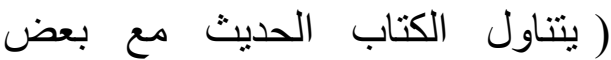

الثخصيات العامة التي لها تأثنر في الفترة الزمنية التي كانو ا بعيشون فيها، فقد دارت

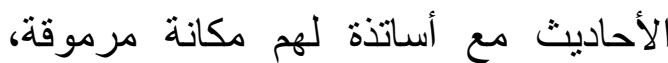
منهم: الأستاذ أمين هويدي، وسامي شرف، الأدة ومحمود السعدني، وثروت أباظة، وجيهان ونيان

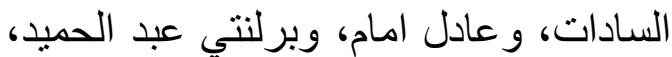
و غيرهم من أهم أحداث مرت في حياة كل وبرل
الأوركستر في الموسيقى الغربية على كثير

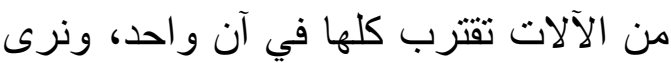
أن بتهوفن خير' مَن يمثل الموسيقى الأوربية. 119

دـ مصطفى الفقي رائد التحديث في الفكر السياسي العربي، مجموعة الصالون

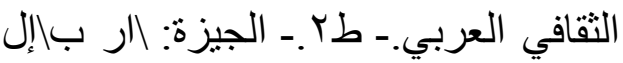

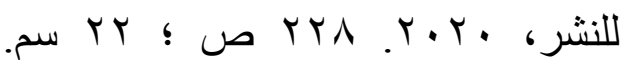
( سلسلة إصدارات الصالون الثقافي العربي)

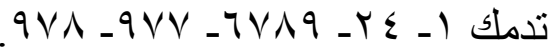
الدكتور مصطفى الفقي نقطة ضوء ساطعة في حياتنا المصرية، القاضي بلا

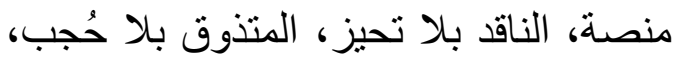

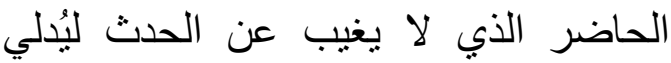
بر أي له مصداقيته وحداثته، المحتفى به في

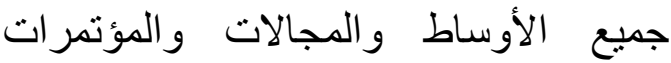
و الندوات و المناسبات العامة و الخاصة، لسان العرب في أي محمل يتطلول فيه الغرب

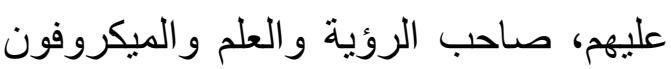

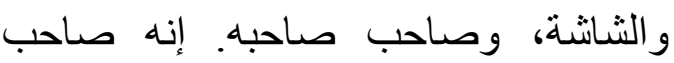
عقلية مفهرسة في دقة الكمبيوتر ، يستطيع أن يكتب في عدة موضوعات في وقت واحد دون أن يتشتت أو يفقد التركيز، فوفو فهو كاتب وفي موهوب يعرف كيف يخاطب عموم القراء دون أن يبتذل أو يترخص، فهو يكتب بروح

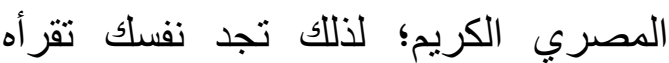
بشهية، حتى و إن كنت مختلفًا معه في الر أي. 
والحرب عند قدماء المصريين، والمرأة في الفن المصري القديم، والزواج عند قدماء المصريين، ومن قصص البردي، الخائنة في القصص المصري القديم، وأثباح الفر اعنة، والعادات الفرعونية الباقية في مصر إلى

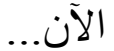

$$
\text { التاريخ العام- للعرب والمسلمين }
$$

Ir

دراسات في تاريخ العالم العربي المعاصر، تأليف: عبد الحكيم الطحاوي.-

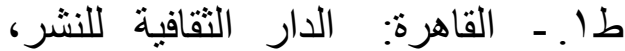
(9. 19 تدمك r- צ يعد تاريخ العالم العربي المعاصر ضمن سلسلة تربط بين الماضي و الحاضر منذ أن

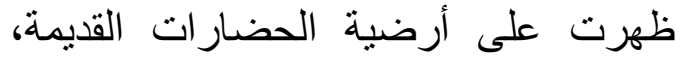
وكانت مهبط الديانات السماوية ومنارة العالم أثناء الحضارة الإسلامية، حيث يتميز العالم العربي بموقع متوسط من الكرة الأرضية ويتحكم بعدد من المضايق الإستراتيجية و الموارد الطبيعية التي جعلت دن أراضيه أحد أهم المناطق الحيوية في العالم، ويقدم دراسة تهدف لإعطاء المعلومة الميسرة عن

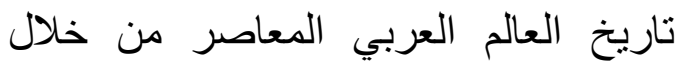
دراسة كل دولة عربية على حدة بدًاية بجمهورية مصر العربية والمملكة العربية السعودية جناحي الأمة العربية، ثم التطرف لإنه للاول العربية الآسيوية، ثم الدول العربية العبية

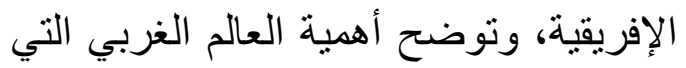

IYT

هرمس العرب، بين حكيم وثني إلى بني

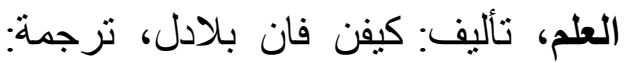

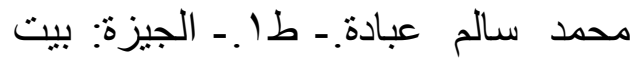

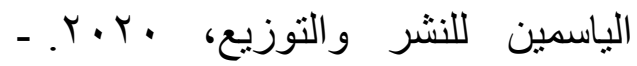
يشتمل على إرجاعات ببليوجر افية.

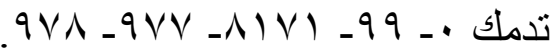

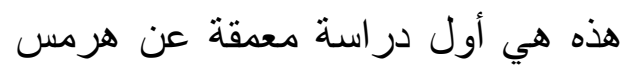

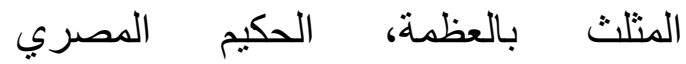
الأسطوري الذي نسب إليه أعمال كثيرة في

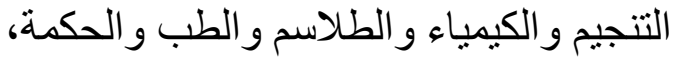
كما يتجلى في الكتابات العربية المبكرة من ون ولن كان يعتقد المؤلفون العرب المبكرون أنه هرمس المثلث بالعظمة، وكيف وصلو ا إلى لى لهون هذا الاعتقاد ؛ الكتاب الذي بين أيدينا محاولة

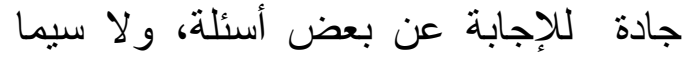
حضرة أسطورة ظلت بالغة التأثير في تاريخ الفكر العالمي حتى وقت قريب.

M

عادات فرعونية باقية في مصر إلى الآن،

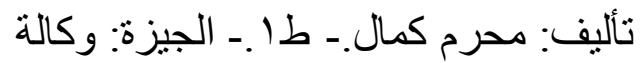

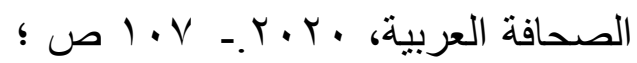
(s)

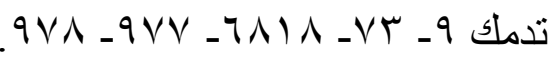

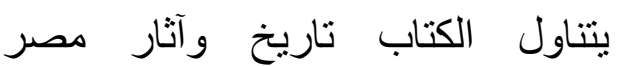
القديمة، وأيضًا المستكثفين الإنجليز للآثار المصرية، ويتناول عددًا من الموضو عات، الإنيات منها: الأثريون الإنجليز في مصر، والنيارل وآثارنا التي لم تكثف بعد، وأبو الهول... ذلك اللغز الخالد، و التبرج عند قدماء المصريين، 
جعلته مستهدفًا من القوى الاستعمارية منذ أكثر من قرن من الزمان، وحتى أيامنا المعاصرة. - انز

iro

الحضارات القديمة: مصر والثرق،

تأليف: رمسيس رياض، وجورج الته صليب

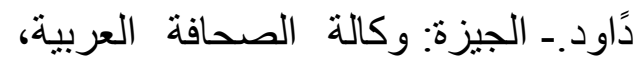

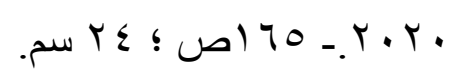

منذ أقدم العصور في الحوض الثرقي

للبحر المتوسط وغرب آسيا ومصر تدين لها

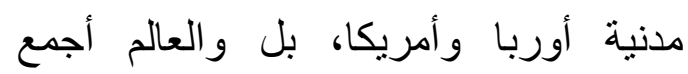

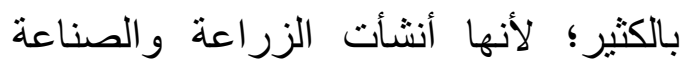

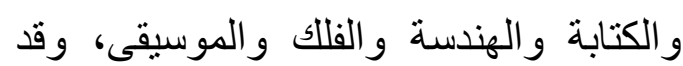
كانت مصر بحكم موقعها ووجود الصحاري على جانبيها، و البحر في شمالها أسعد حظًا من بلاد ما بين النهرين مع ذللك، لأن هناك صلة بينهم منذ أقدم العصور. بلدد مان

IrT

مصر في القرن التاسع عشر، أو محمد علي ومن خلقوه إلى الاحتلال البريطاني

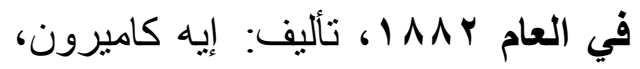
ترجمة وتقديم : صبري محمد حسن.

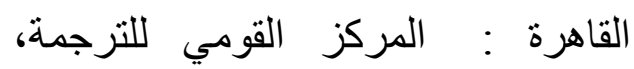

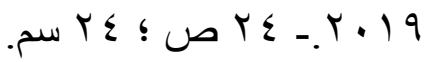

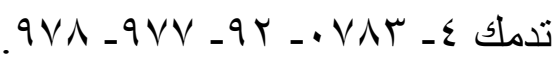

